Portland State University

PDXScholar

Environmental Science and Management

Faculty Publications and Presentations

Environmental Science and Management

$4-2018$

\title{
Assessing Transboundary Wildfire Exposure in the Southwestern United States
}

\author{
Alan A. Ager \\ USDA Forest Service \\ Palaiologos Palaiologou \\ USDA Forest Service \\ Cody Evers \\ Portland State University, cevers@pdx.edu \\ Michelle A. Day \\ Oregon State University \\ Ana M.G. Barros \\ Oregon State University
}

Follow this and additional works at: https://pdxscholar.library.pdx.edu/esm_fac

Part of the Environmental Monitoring Commons, Forest Sciences Commons, and the Natural

Resources Management and Policy Commons

Let us know how access to this document benefits you.

\section{Citation Details}

Ager, A. A., Palaiologou, P., R. Evers, C., Day, M. A., \& G. Barros, A. M. (2018). Assessing transboundary wildfire exposure in the southwestern United States. Risk analysis.

This Article is brought to you for free and open access. It has been accepted for inclusion in Environmental Science and Management Faculty Publications and Presentations by an authorized administrator of PDXScholar. Please contact us if we can make this document more accessible: pdxscholar@pdx.edu. 


\title{
Assessing Transboundary Wildfire Exposure in the Southwestern United States
}

\author{
Alan A. Ager, ${ }^{1, *}$ Palaiologos Palaiologou, ${ }^{2}$ Cody R. Evers, ${ }^{3}$ Michelle A. Day, ${ }^{4}$ \\ and Ana M. G. Barros 5
}

\begin{abstract}
We assessed transboundary wildfire exposure among federal, state, and private lands and 447 communities in the state of Arizona, southwestern United States. The study quantified the relative magnitude of transboundary (incoming, outgoing) versus nontransboundary (i.e., self-burning) wildfire exposure based on land tenure or community of the simulated ignition and the resulting fire perimeter. We developed and described several new metrics to quantify and map transboundary exposure. We found that incoming transboundary fire accounted for $37 \%$ of the total area burned on large parcels of federal and state lands, whereas $63 \%$ of the area burned was burned by ignitions within the parcel. However, substantial parcel to parcel variation was observed for all land tenures for all metrics. We found that incoming transboundary fire accounted for $66 \%$ of the total area burned within communities versus $34 \%$ of the area burned by self-burning ignitions. Of the total area burned within communities, private lands contributed the largest proportion $(36.7 \%)$, followed by national forests $(19.5 \%)$, and state lands (15.4\%). On average seven land tenures contributed wildfire to individual communities. Annual wildfire exposure to structures was highest for wildfires ignited on state and national forest land, followed by tribal, private, and BLM. We mapped community firesheds, that is, the area where ignitions can spawn fires that can burn into communities, and estimated that they covered 7.7 million ha, or $26 \%$ of the state of Arizona. Our methods address gaps in existing wildfire risk assessments, and their implementation can help reduce fragmentation in governance systems and inefficiencies in risk planning.
\end{abstract}

KEY WORDS: Community wildfire protection; network analysis; risk governance; scale of risk

${ }^{1}$ USDA Forest Service, Rocky Mountain Research Station, Missoula Fire Sciences Laboratory, Missoula, MT, USA.

${ }^{2}$ USDA Forest Service, International Visitor Program and Portland State University, Department of Environmental Science and Management, Portland, OR, USA.

${ }^{3}$ Department of Environmental Sciences and Management, Portland State University, Portland, OR, USA.

${ }^{4}$ Oregon State University, College of Forestry, Forest Engineering Resources \& Management, Corvallis, OR, USA.

${ }^{5}$ Oregon State University, College of Forestry, Forest Ecosystems \& Society, Corvallis, OR, USA.

*Address correspondence to Alan A. Ager, USDA Forest Service, Rocky Mountain Research Station, Missoula Fire Sciences Laboratory, 5775 US Highway 10W, Missoula, MT 59808, USA; tel: +1-541-969-8683; aager@fs.fed.us.

\section{INTRODUCTION}

Wildfire impacts to developed areas continue to escalate on a global basis, in particular in temperate ecosystems (Moritz et al., 2014). Numerous and well-known drivers of wildfire losses to social and ecological values have been widely discussed, including increasing development pressure in wildlands (Radeloff et al., 2005, Stewart, Radeloff, Hammer, \& Hawbaker, 2007), climate anomalies (Jolly et al., 2015; Trigo et al., 2006), rural abandonment (Benayas, Martins, Nicolau, \& Schulz, 2007; MacDonald et al., 2000), removal of fire from fire-prone systems (Collins, Stephens, Moghaddas, \& Battles, 2010; North, Collins, \& Stephens, 2012), and poor 
community response to wildfire events (Calkin, Thompson, \& Finney, 2015; Williams, 2013). Framing the problem in a broader socioecological systems framework is argued as a way to leverage risk governance to develop cohesive transboundary (i.e., "all lands") wildland fire management strategies to address drivers that perpetuate wildfire problems (Fischer et al., 2016; Steelman, 2016; USDA Forest Service, 2014). Risk governance concepts (Renn, Klinke, \& van Asselt, 2011; van Asselt \& Renn, 2011) were originally stimulated by transboundary risk issues (Lidskog, Soneryd, \& Uggla, 2010, Lidskog, Uggla, \& Soneryd, 2011, USDA Forest Service, 2001), including floods (Van Eerd MC \& Dieperink, 2015), pollution, other environmental hazards (Lidskog et al., 2011), and disease (van Zwanenberg \& Millstone, 2005), but only recently have been discussed in the context of wildfires (UNECE/FAO, 2013; Zaimes et al., 2016). For example, Steelman (2016) argues that current wildfire risk governance is highly fragmented and poorly designed to respond specifically to transboundary wildfire risk. Fragmentation in wildfire risk governance likely contributes to scale mismatches (Cumming, Cumming, \& Redman, 2006) and inefficient planning (Ager, Kline, \& Fischer, 2015). Lidskog et al. (2010) argue that in general, multiple sources of complexity need to be addressed to render transboundary risk issues governable. Still others argue that the two-dimensional definition of risk itself (probability and consequence) is not sufficient to evaluate transboundary risk, since identical risks in these two dimensions could require different treatment (van Asselt \& Renn, 2011) due to the cause of the process by which they were created or sustained. Gardoni and Murphy (2014) proposed a third dimension of risk that should be factored into risk evaluation, the source or cause of risk.

Transboundary wildfire risk results from fragmented landscapes and is amplified by heterogeneity in the drivers of wildfire spread (Finney, 2005) at the scale of a patch, parcel, ownership, or any other defined spatial unit. The process is highly relevant to understand and foster risk governance systems to achieve various goals of U.S. federal wildland fire policy, including fire-adapted landscapes, safe response, and fire-resilient communities (USDA Forest Service, 2014). At the scale of public land parcels in the United States, transboundary risk is primarily an artifact of landscape fragmentation with respect to ownership and administrative fire management jurisdictional boundaries (Ager et al.,
2017). Parcel geometry and relative size of different ownerships set the stage for fire transmission across boundaries (Ager, Day, Finney, Vance-Borland, \& Vaillant, 2014). The problem manifests itself when landowners and institutions have inconsistent attitudes and objectives about fire's role in fire-adapted ecosystems. For instance, public managers are mandated to restore natural fire regimes in fire-adapted forests, and adjacent private landowners are primarily interested in protecting their property, and, in the case of private industrial landowners, generating economic outputs from forest management (Charnley et al., 2015). The transboundary problem is a particular issue in the interface between communities and large tracts of public and private wildlands (Haas, Calkin, \& Thompson, 2015) where natural fire regimes are often in conflict with socioeconomic values and land management goals at the parcel scale (Charnley et al., 2015; Fischer \& Charnley, 2012; Steelman, 2016). Transboundary risk issues are highly relevant to other fire management issues, including recent initiatives to expand the use of both prescribed fire and natural ignitions to reduce fuels and future suppression costs, and restore low severity wildfire in fire-adapted forests (North et al., 2015; Prichard, Stevens-Rumann, \& Hessburg, 2017). Numerous prescribed fires, as well as natural ignitions managed for restoration objectives, have escaped and resulted in substantial damages (Dether, 2005).

A step towards better understanding transboundary wildfire issues is leveraging a growing body of knowledge and technology for large wildfire risk assessment (Ager, Finney, Kalabokidis, \& Moore, 2017; Miller \& Ager, 2013). In the United States, risk assessment technologies have been stimulated by multiple reports from oversight agencies that concluded risk metrics need to be used to prioritize investments in fuel management (OIG, 2016). However, existing risk assessment protocols do not explicitly quantify transboundary risk and the implications in terms of risk mitigation and governance. A good example is the risk assessment process used by state agencies in the United States (Wolf \& Buckley, 2010). This assessment has been initially completed for the western U.S. states and is now being refined on a state-by-state basis and implemented in Wildfire Risk Assessment Portals (WRAPs) for each of the 17 western states for use by the public and professionals (WWWRA, 2013b). These risk assessments are based on pixel-level indices that identify communities that need to engage in community wildfire 
protection planning (CWPP) (Ellison et al., 2015). Similar methods have been developed for fine-scale community wildfire risk planning (Headwaters Economics, 2016). Both systems use pixel-scale estimates of fire behavior rather than simulations of large fire events, and thus the potential impacts from large fires on risk are not fully exposed. Newer methods developed by Forest Service researchers use large fire simulation (Dillon, Menakis, \& Fay, 2015; Scott, Thompson, \& Calkin, 2013) but lack frameworks to consider transboundary wildfire transmission.

To advance current risk assessment methods to recognize the complexities of transboundary risk governance (USDA Forest Service, 2001; Zaimes et al., 2016) and to specifically address implications for "all lands" risk management (USDA Forest Service, 2014), we describe a number of newer risk assessment concepts based on the core principle that transboundary risk has a spatial and functional scale that is determined by a host of social, institutional, biophysical, and ecological factors (Table I). We use the state of Arizona in the southwest United States as a case study to examine transboundary wildfire exposure among land tenures and communities and describe exposure profiles for each land tenure and community. Arizona is prone to large wildfires, and rapidly expanding exurban growth has created conflicts between fire and people. We ask how the geography of land tenures intersected on local fire regimes in a typical fire-prone state in the western United States sets the stage for fire transmission across public-private boundaries, and what metrics are useful to quantify the resulting exposure. We do not explicitly consider risk to avoid issues with tenure-specific values and their influence on risk, and assume that most transboundary exposure carries substantial risk in one form or another. We mapped the spatial structure of wildfire risk to Arizona's communities in terms of the amount and number of contributing land tenures and discuss the implications for managing wildfire risk. Our results illustrate how a transboundary assessment of wildfire risk can facilitate managing wildfire risk at a multijurisdictional scale and facilitate dialogues between federal, state, and private land management organizations and the respective communities they potentially impact. Results from the study can be coupled with local information on community protection activities to prioritize state and local funding. Expansion of our efforts in other western U.S. states will lead to the characterization of complex wildfire networks that can inform local and regional risk governance and planning processes to factor wildfire connectivity into state-scale risk assessments (WWWRA, 2013b), and lead to the development of community protection activities individualized by the source of wildfire and fire management objectives on the source land tenures.

\section{MATERIALS AND METHODS}

\subsection{Study Area}

The study area was the state of Arizona, covering approximately $300,000 \mathrm{~km}^{2}$. The state contains 447 communities and cities with a total population of 6,392,017 residents (2010 census), $65 \%$ of which live in Maricopa County (surrounding Phoenix). The remaining $35 \%$ of Arizona's population is scattered among the other 14 counties in 403 communities. Federally managed land accounts for $41 \%$ of the study area and is distributed among five federal agencies: Forest Service (FS), National Park Service (NPS), Bureau of Land Management (BLM), military and energy infrastructure lands (DOD/DOE), and the U.S. Fish \& Wildlife Service (FWS) (Fig. 1a and Table II). Arizona has extensive national forests, including the Apache-Sitgreaves, Coconino, Kaibab, Prescott, and Tonto. Native American tribal lands occupy over a quarter of Arizona, including the Navajo Nation, the Hopi Tribe, the Havasupai Tribe, the Gila River Indian Community, the Tohono O'odham Nation, the White Mountain Apache Tribe, and the San Carlos Apache Tribe. Private and state lands account for $12.3 \%$ and $11.9 \%$ of Arizona, respectively.

Seven distinct ecoregions characterize the state's landscape, that is, the Arizona/New Mexico Mountains, extending from central Arizona to the northern boundary covering $21.6 \%$ of Arizona; the Chihuahuan Deserts in the southeast $(0.9 \%)$, interspersed with Madrean Archipelago; Madrean Archipelago (12\%) in the southeast; the easternmost extension of the Sonoran Desert in the southwest (Sonoran Basin and Range; 30.4\%); the Mojave Basin and Range in the northwest (5.2\%); the Arizona/New Mexico Plateau to the north (26.3\%); and the Colorado Plateaus along the northern border of the state (3.6\%) (Omernik \& Griffith, 2014). Vegetation zones include alpine tundra on the San Francisco Peaks above timberline at elevations exceeding 3,340 $\mathrm{m}$, spruce-alpine fir forests on and around the summits of the highest mountains, and montane conifer 
Table I. Key Concepts and Metrics for Assessment and Mitigation of Transboundary Wildfire Issues on Multiple Tenure Landscapes

\begin{tabular}{|c|c|c|c|}
\hline Concept & Explanation & Metrics & Example \\
\hline Transboundary risk & $\begin{array}{l}\text { Conditions and events on one parcel } \\
\text { affect risk and exposure on another }\end{array}$ & $\begin{array}{l}\text { Incoming fire, outgoing fire, } \\
\text { nontransmitted fire } \\
\text { (self-burning) }\end{array}$ & Fig. 2 \\
\hline Scale of risk & $\begin{array}{l}\text { Wildfire spread between ignitions and } \\
\text { impacted features }\end{array}$ & $\begin{array}{l}\text { Distance to ignition from affected } \\
\text { parcel, average fire size burning } \\
\text { a particular feature, fireshed } \\
\text { area relative to populated place }\end{array}$ & $\begin{array}{l}\text { Ager et al., 2015; } \\
\text { Fig. } 12\end{array}$ \\
\hline Wildfire networks & $\begin{array}{l}\text { Wildfire connectivity and } \\
\text { interdependence among land tenures }\end{array}$ & $\begin{array}{l}\text { Network density, node degree, } \\
\text { directed node degree, centrality, } \\
\text { betweenness }\end{array}$ & Figs. 4,5 , and 9 \\
\hline Community firesheds & The spatial scale of risk to communities & $\begin{array}{l}\text { Zone around communities that } \\
\text { includes all areas that } \\
\text { potentially transmit fire into a } \\
\text { community }\end{array}$ & Figs. $11,12 \mathrm{e}$ \\
\hline Scale mismatches & $\begin{array}{l}\text { Difference between spatial scale of risk } \\
\text { and planning boundaries }\end{array}$ & $\begin{array}{l}\text { Fireshed area relative to } \\
\text { community wildfire protection } \\
\text { planning boundary }\end{array}$ & Ager et al., 2015 \\
\hline $\begin{array}{l}\text { Community wildfire } \\
\text { characterization }\end{array}$ & $\begin{array}{l}\text { Fire metrics that describe wildfire } \\
\text { exposure on the affected part of } \\
\text { communities and associated wildland } \\
\text { urban interface (WUI), calculated at } \\
\text { the WUI-polygon scale }\end{array}$ & $\begin{array}{l}\text { Expected area burned per year, } \\
\text { flame length, fuel models, } \\
\text { farmland, etc. }\end{array}$ & Ager et al., 2017 \\
\hline $\begin{array}{l}\text { Transboundary risk } \\
\text { governance }\end{array}$ & $\begin{array}{l}\text { Institutions, rules conventions, processes, } \\
\text { and mechanisms by which } \\
\text { transboundary risk is managed }\end{array}$ & $\begin{array}{l}\text { Socioeconomic and ecological } \\
\text { costs caused by wildfire } \\
\text { disasters }\end{array}$ & $\begin{array}{l}\text { Lidskog et al., } \\
2010\end{array}$ \\
\hline
\end{tabular}

forests that grow along the southern rim of the Colorado Plateau. Pinyon-juniper woodland is mostly found in the northern half of Arizona and encinal and Mexican oak-pine woodlands in the southeast (evergreen oaks or mixtures of oak, juniper, and Mexican pinyon). The interior chaparral type extends in a discontinuous band running southeast from Kingman, through Prescott and Payson, continuing to the southeast below the Mogollon Rim. Arizona's interior chaparral differs significantly from that of California in terms of prevailing climate (receiving less annual precipitation), growth patterns, average height and species of shrubs, and the composition of understory grasses and forbs (Schalau \& Twaronite, 2010). Grasslands are divided into three different types: mountain meadow, plains, and desert. Table III shows the proportion of the different fuel types and nonburnable area in each ecoregion.

Natural (lightning) and human-caused large fires within the study area have burned 2.5 million ha during the 1984-2015 period ( $8.1 \%$ of total Arizona's area) (MTBS Data Access, 2017). This translates to $0.28 \%$ of the burnable land per year. Based on the Short (2014) database (1992-2011), natural ignitions accounted for $47.4 \%$ of area burned and human ignitions accounted for 52.6\% (1.1 million ha). Between
1976 and 2016, 22 large wildfires (>1,000 ha) were recorded, burning approximately 800,000 ha of forest and other lands. The Wallow Fire (2011) is the largest recorded fire in the state and burned 220,000 ha, the majority on the Apache-Sitgreaves National Forest $(93 \%)$, followed by tribal $(4.2 \%)$, private $(2 \%)$, and state lands $(0.8 \%)$. The Rodeo-Chediski Fire (2002) burned 190,000 ha of ponderosa pine, pine-oak, and juniper-pinyon forests on tribal $(60.5 \%)$, FS $(37.9 \%)$, and private lands $(1.6 \%)$, with more than 400 burned structures. The Cave Creek Complex Fire (2005) burned 100,000 ha on FS $(92.5 \%)$, state $(4.6 \%)$, private $(1.6 \%)$, and BLM lands $(1.2 \%)$, and destroyed structures and natural monuments.

\subsection{Spatial Data on Land Ownership and Communities}

We used polygon data from the U.S. Census Bureau populated places (U.S. Census Bureau, 2016) and the SILVIS wildland urban interface (WUI) (Radeloff et al., 2005) databases to define communities within Arizona. The SILVIS WUI defines WUI as the area where houses meet or intermingle with undeveloped wildland vegetation, classified according to structure density (one structure per 

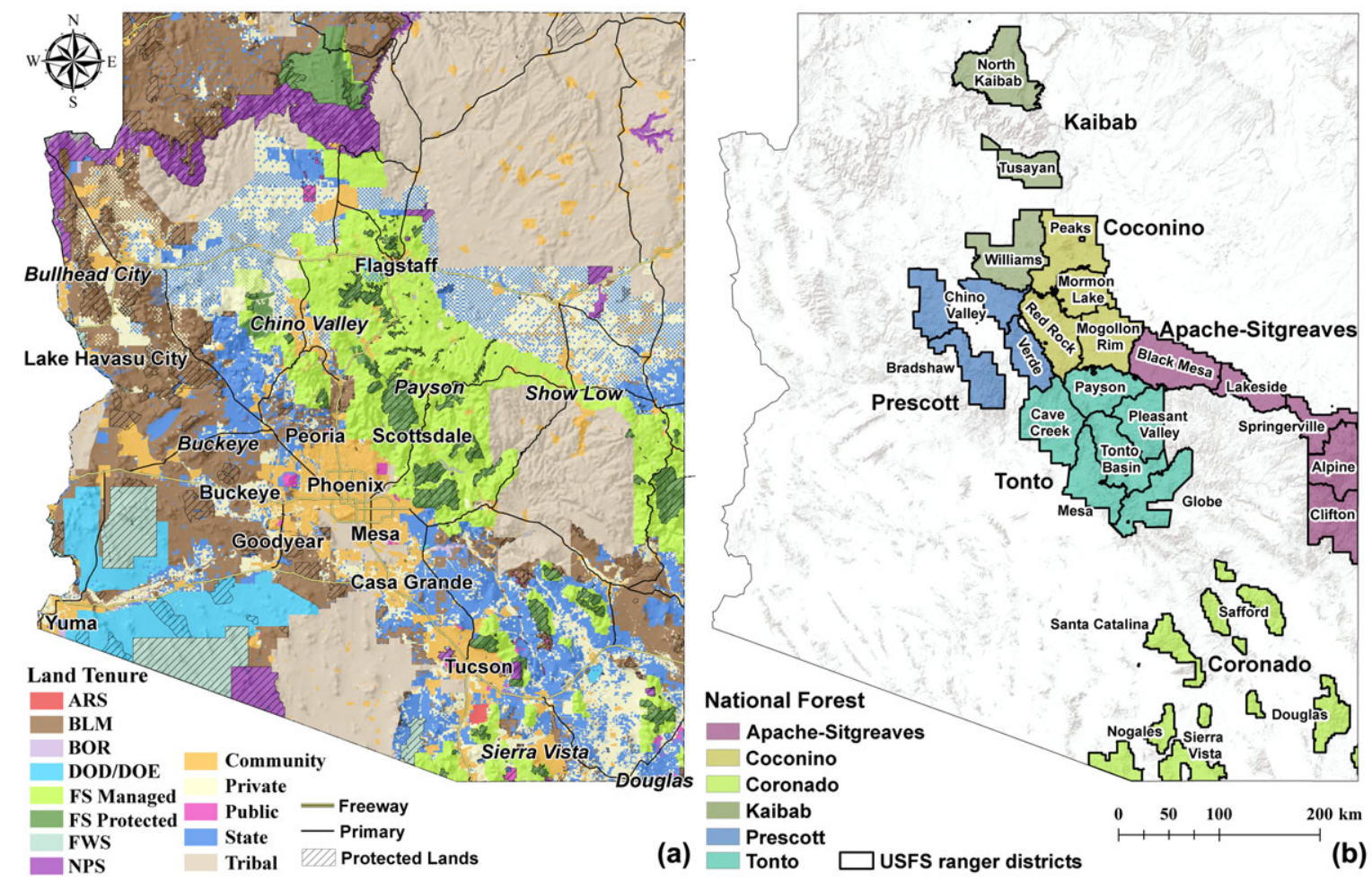

(a)

Tonto $\square$ USFS ranger districts

(b)

Fig. 1. (a) Land tenure map for the state of Arizona with protected areas (dashed). Land tenures are combinations of ownership and protection status. Checkerboard effect appears between state and private land tenures east and west of Flagstaff. ARS, Agricultural Research Service; BLM, Bureau of Land Management; BOR, Bureau of Reclamation; DOD, Department of Defense; DOE, Department of Energy; FWS, U.S. Fish \& Wildlife Service; FS, Forest Service; NPS, National Park Service. See Table II for land tenure details. (b) National forest boundaries with ranger districts.

16 ha minimum) and distance to wilderness vegetation, with further classifications into intermix (housing and vegetation intermingle) and interface (housing in the vicinity of contiguous vegetation). Populated places were identified from the census populated places data and intersected WUI polygons (U.S. Census Bureau, 2016). Final community boundaries of the 447 communities were derived by assigning each WUI polygon outside populated place boundaries to its closest community (all polygons within an estimated 45 minutes travel time).

The ownership and management capability layer was compiled using the USGS Protected Area Database (PAD) (USGS Protected Areas Database of the United States (PAD-US), 2016) for the United States, and the Integrated Landscape Assessment Project (ILAP) (Gaines, Hemstrom, Kagan, \& Salwasser, 2013). Managed lands were identified using the ILAP forest management categories (codes 4, 5, and 6) to determine portions of land tenures where mechanical fuel management activities could be undertaken and potentially mitigate transboundary fire events (Fig. 1). We use the term land tenure to describe the combined classification of ownership and management capability. Communities and ownership-management layers were combined to create a new layer with 13 land tenures. We then further separated FS lands into ranger districts (RD) (Fig. 1b).

\subsection{Wildfire Simulation}

We used wildfire simulation data reported by Short, Finney, Scott, Gilbertson-Day, and Grenfell (2016) that were generated using 2012 LANDFIRE data (LANDFIRE, 2016) and the FSim model (Finney, McHugh, Grenfell, Riley, \& Short, 2011). The data have been summarized in a number of previous papers (Ager et al., 2014; Ager, Day, Short, \& Evers, 2016). The data consist of predicted wildfire ignition locations and fire perimeters for the study area. FSim uses the minimum travel time (MTT) algorithm to calculate fire growth by Huygens's principle, where growth and behavior of the fire 
perimeter is modeled as a vector or wave front (Finney, 2002; Richards, 1990). The simulations were performed with a spatial stratification system according to federal interagency fire planning units (FPU). Models for each FPU were calibrated based on spatiotemporal ignition patterns over the past 30 years (Short, 2014, 2016). Surface and canopy fuel data for wildfire simulations were obtained from the national LANDFIRE data set (Rollins, 2009), consistent and widely used fuel data available for the United States (Krasnow, Schoennagel, \& Veblen, 2009, Rollins, 2009). Variables used in fire modeling with FSim included elevation (m), slope (degrees), aspect (azimuth), fuel model (Scott \& Burgan, 2005), canopy cover (\%), canopy base height $(\mathrm{m})$, canopy height $(\mathrm{m})$, and canopy bulk density $\left(\mathrm{kg} / \mathrm{m}^{3}\right)$ (Ryan \& Opperman, 2013).

Meteorological conditions for fire simulations for each FPU were obtained from a Remote $\mathrm{Au}$ tomatic Weather Station (RAWS) (Zachariassen, Zeller, Nikolov, \& McClelland, 2003). Each station was selected based on local FS fire staff recommendations. Selected RAWS had a minimum of 20 years of available weather records and reflect the local weather conditions (i.e., wind velocity) associated with the fire season for each FPU. Fire simulations were performed at $270 \times 270 \mathrm{~m}$ pixel resolution, a scale that allowed for relatively fast computation times while maintaining reasonable spatial resolution in vegetation and topographic inputs.

The data set contained 1.1 million ignitions, corresponding to 20,000 to 30,000 fire seasons (depending on FPU) depicting the historical ignition patterns of the study area. Simulation outputs included fire perimeters, ignition locations, and probability-intensity grids. Validation of FSim simulation outputs was performed by comparison of actual versus predicted fire perimeters and fire size distributions (Finney et al., 2011, 2011). The outputs used in this study were deemed adequate for examining broad landscape patterns of fire exposure within the study area.

\subsection{Transmission Analysis}

Analysis of wildfire transmission was conducted at both the landowner and community scale, similar to the methods described in Ager et al. (2017). Fire perimeter outputs and ignition locations were intersected with the polygon land tenures and communities to quantify the area burned. For community polygons, the number of structures affected 
Table III. Fuel Model (Scott \& Burgan, 2005) Composition of the Seven Ecoregions of Arizona (Omernik \& Griffith, 2014)

\begin{tabular}{lrrrrrrr}
\hline & \multicolumn{7}{c}{ Fuel Model Categories (\%) } \\
\cline { 2 - 6 } & NB & GR & GS & SH & TU & TL & Area (ha) \\
\hline Arizona/New Mexico Mountains & 3.5 & 30.7 & 37.6 & 8.5 & 3.2 & 16.5 & $6,383,831$ \\
Arizona/New Mexico Plateau & 14.9 & 41.5 & 19.7 & 23.0 & 0.4 & 0.5 & $7,770,433$ \\
Chihuahuan Desert & 13.3 & 18.0 & 53.8 & 14.6 & 0.2 & 0.1 & 257,009 \\
Colorado Plateau & 22.3 & 22.5 & 31.2 & 23.8 & 0.1 & 0.1 & $1,051,444$ \\
Madrean Archipelago & 3.5 & 35.6 & 40.5 & 17.8 & 0.8 & 1.8 & $3,532,661$ \\
Mojave Basin and Range & 18.6 & 14.9 & 54.5 & 10.8 & 1.1 & 0.1 & $1,541,704$ \\
Sonoran Basin and Range & 11.0 & 5.6 & 60.4 & 22.8 & 0.1 & 0.1 & $8,975,885$ \\
\hline
\end{tabular}

${ }^{\mathrm{a}} \mathrm{NB}=$ nonburnable; $\mathrm{GR}=$ grass; $\mathrm{GS}=$ grass-shrub; $\mathrm{SH}=$ shrub; $\mathrm{TU}=$ timber understory; $\mathrm{TL}=$ timber litter.

by simulated fire perimeters was calculated using the structure density of the polygon and the proportion of the polygon burned (i.e., structures assumed to be randomly located within each SILVIS WUI polygon). Annualized values of area burned and structures exposed were derived from the intersection of the polygon land tenure layers (ownership, WUI, community) with simulated wildfire perimeters, adjusted by the number of fire season replicates (20,000-30,000 depending on the analysis area in the FSim simulation) (Short et al., 2016).

Information about area burned in each land tenure/community and number of structures exposed was then tagged to the original ignition location. We summarized wildfire transmission by land tenure and community by calculating transmitted fire (TF) based on fire ignition location and spread. We then partitioned TF into three categories: incoming fire (TF-IN), outgoing fire (TF-OUT), and nontransmitted (non-TF). The area of nontransmitted fire per ignition measures the area burned by ignitions within the land designation (i.e., self-burning). Using the land tenure spatial data set we analyzed wildfire transmission to understand three specific wildfire transmission patterns: (1) from large land tenures to communities, (2) among the large land tenures, and (3) among the administrative subunits within federal large land tenures (e.g., RDs) (Fig. 1b).

\subsection{Networks}

We used values of transmitted burned area among major land tenures and communities to create wildfire networks showing the connectivity between land tenures. Wildfire networks are comprised of nodes corresponding to land tenures or communities, and edges (connections) that represent transmission between nodes, e.g., total fire transmitted between public lands to state lands. Because wildfire transmission was partitioned into incoming and outgoing fire, network edges are directional, that is, they distinguish the relative strength of wildfire transmission from, to, and within each node. The strength of the wildfire connection in terms of the area burned can be represented by the width of the edge in network diagrams. Node degree measures the number of linkages for each node and is widely used in network analysis to indicate how central a node is in the network, often interpreted as an indicator of connectivity and influence (Borgatti, Everett, \& Johnson, 2013). The number of linkages present in the network compared to the maximum possible is the network density, which represents the overall connectedness in the network. We used the igraph network package (Csardi \& Nepusz, 2006) in $\mathrm{R}$ (R Core Team, 2014) to calculate whole network and parcel-specific measures on the number and strength of wildfire transmission linkages.

\subsection{Firesheds}

We used wildfire simulation results to identify the area where large fires are likely to ignite and affect structures in the WUI and populated places. These "firesheds" define the biophysical risk containers in and around communities and the sources of risk in terms of ownership, fire regime, and management capability; thus we consider firesheds to include the populated places and the WUI around them (Ager, Bahro, \& Barber, 2006; Scott, Thompson, \& Gilbertson-Day, 2015). By applying the inverse distance weighting (IDW) method for multivariate interpolation of ignition points, a continuous $1 \mathrm{~km}^{2}$ grid was generated using a $5 \mathrm{~km}$ fixed search radius for the entire study area. To convert the continuous surface to a discrete boundary (i.e., the fireshed), we used a threshold of 0.0005 , meant to capture ignition locations where there was at least a nominal (1\%) chance of exposure. Finally, fireshed 
polygons were intersected with the land tenure map and the 2014 LANDFIRE 40 Scott and Burgan Fire Behavior Fuel Models layer (Scott \& Burgan, 2005) to calculate the fireshed area by land tenure and fuel model, respectively.

\subsection{Spatial Scale of Exposure}

We calculated and mapped six measures to illustrate the spatial scale and complexity of wildfire exposure in relation to the geography of land tenures. Each measure was calculated at $500 \times 500 \mathrm{~m}$ pixel resolution. Three of the metrics describe the scale and composition of fire effects that ignite elsewhere and arrive at a given pixel. The source fire complexity index (SFCI) estimated the number of unique land tenures (including communities) that contributed fire to a given pixel. The fire size arrival index (FSAI) measured the average fire size (ha) that burned each pixel. The ignition distance index (IDI) was calculated as the average distance $(\mathrm{km})$ between the fire ignition and the centroid of the WUI polygon it affected, weighted by the number of structures affected. Three additional metrics were developed to characterize how fires that ignite in a given pixel affect other locations. The fire size potential index (FSPI) was the average fire size (ha) that was generated by an ignition in each pixel. Here, each simulated fire was attributed to the ignition point and the points smoothed to create a continuous raster coverage. The structure exposure index (SEI) measured the number of structures per $\mathrm{km}^{2}$ per year exposed from an ignition in a given pixel. SEI was created by assigning each ignition point with the number of structures affected by the fire generated from that ignition, and smoothing the resulting point map. The self-burning index (SBI) measured the percentage of self-burning, that is, from an ignition inside the land tenure parcel versus incoming fire from a different land tenure, averaged across all fires.

\section{RESULTS}

\subsection{Fire Transmission Among Land Tenures}

Predicted annual area burned was highest on managed national forests (FS-M) and BLM, with more than ca. 24,500 ha of burned area per year. Private, state, and tribal lands experienced slightly less wildfire and altogether accounted for $85 \%$ of all burned area (Fig. 2a and Table IV). Analysis of the simulated ignitions layer revealed that the majority of burned area resulted from ignitions initiated inside FS managed areas (37\%), followed by tribal (18\%), BLM $(12 \%)$, and private lands $(10 \%)$, with a small number of fires ignited inside protected areas (12\%).

We observed major differences among land tenures in the amount of transmitted fire (Fig. 2). Incoming fire averaged $28 \%$ of the total area burned (range 13-43\%) whereas outgoing fire averaged $31 \%$ among land tenures (range 15-51\%) with $46 \%$ of all fire activity nontransmitted. The majority of land tenures had almost equal percentages of incoming and outgoing fire. Land tenures such as BOR, public, community, private, and state had the smallest percentages of nontransmitted fire, with almost equal proportions of incoming and outgoing fire (Fig. 2b). The same tenures also had the smallest parcel size (Fig. 2c), which explains the high transmission of fire and the low amount of self-burning. BOR, ARS, and public lands together accounted for less than $0.5 \%$ of the state's total area, yet had a high percentage of annually burned area $(>0.5 \%$ each; Fig. 2d). Communities and public lands had the largest proportion of incoming fires $(>40 \%)$, with similar proportions for outgoing fires (Fig. 2b).

FWS and DOD/DOE were similar in terms of fire transmission and are located in the same region within AZ. State and private tenures intermix across the landscape, forming a checkerboard, and thus increasing the relative amount of transmitted fire. In contrast, the largest proportions of nontransmitted fires can be found on land tenures with few and large polygons (tribal, DOD/DOE, FWS, and NPS; Fig. 2b). Total fire transmitted and average parcel size were correlated with outliers represented by those land tenures with relatively high numbers of parcels (Fig. 3). Large differences existed between managed and protected FS lands, with the largest average parcel size and highest proportion of nontransmitting fire for FS-M (Figs. 2a and 2c). The BLM is a major landowner in the state $(16.4 \%)$ but has a relatively small average parcel size (Fig. 2c), with five very large parcels and $<1,000$ smaller parcels in a checkerboard pattern. Tribal lands consist of few, very large polygons with a very high average parcel size (Fig. 2c), resulting in a high proportion of nontransmitting fire but, overall, a small percentage of area burned annually $(0.16 \%)$. Tribal lands have a large proportion of nonburnable fuels $(14 \%)$, which accounts for the low annual rate of burning (Table II).

The wildfire transmission network (Fig. 4) provided a broad overview of fire exchange among 

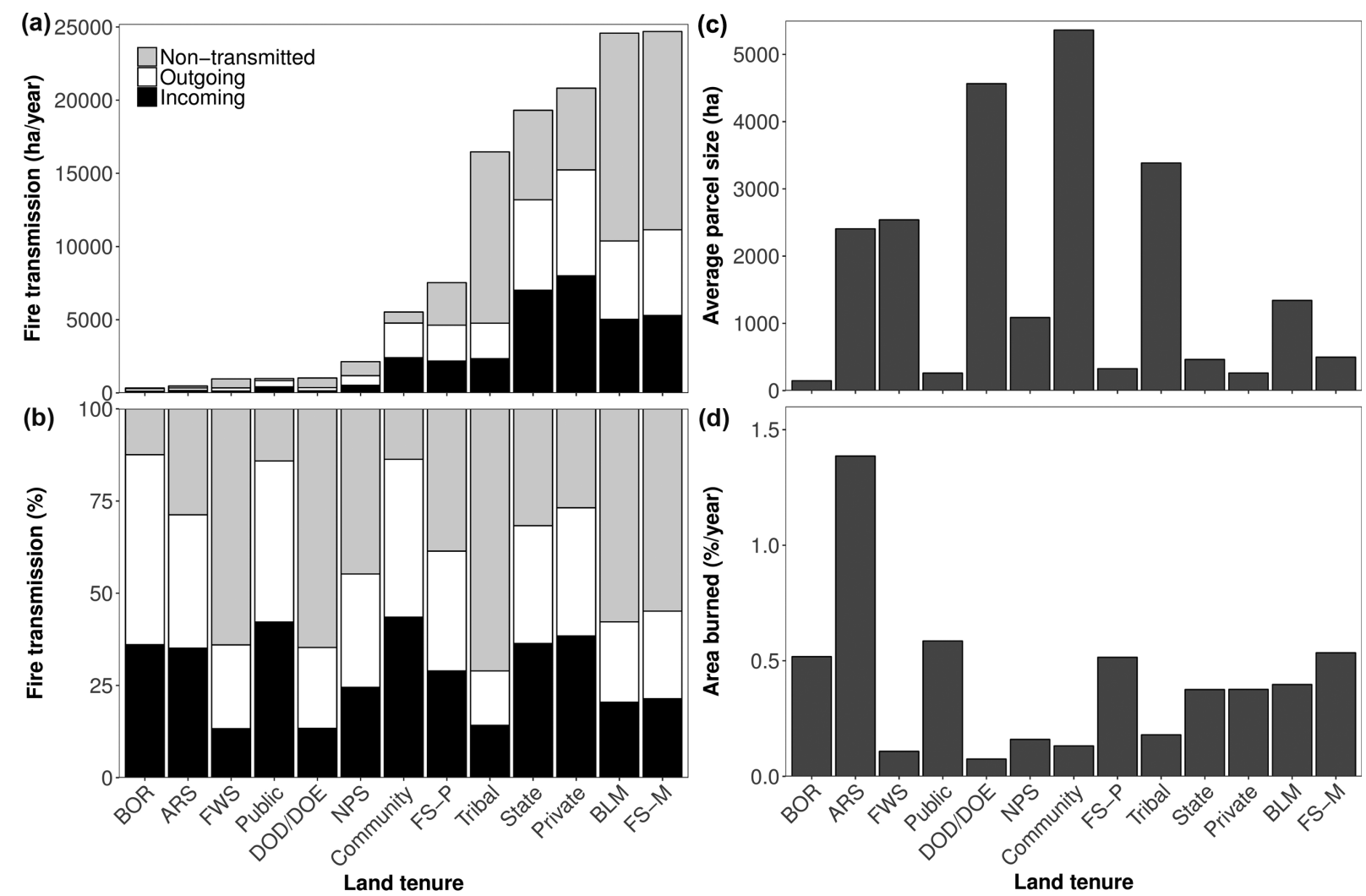

Fig. 2. Relative amounts of incoming, outgoing, and nontransmitted wildfire for the major land tenures in Arizona by (a) total simulated annual area burned and (b) percent within each land tenure. Panels on the right show the average parcel size (c) and the percent annual area burned of the total land tenure size (d). See Table II for land tenure descriptions.

the land tenures and shows that fire was transmitted between all 13 land tenures via 58 network edges (i.e., directed edges), corresponding to a network density of 0.37 (meaning that $37 \%$ of all possible linkages between land tenures was present; edges with transmission $<60 \mathrm{ha} /$ year and self-burning were excluded). Connectivity of individual nodes in the land tenure network, as measured by total node degree (sum of in and out degree), varied from a low of $1(\mathrm{BOR})$ to a high of 17 (BLM) for the filtered network. Land tenures with lower node degree received and transmitted fire to a lesser extent than land tenures with higher node degree.

The transboundary wildfire transmission network (Fig. 5) among major federal administrative subunits showed that the average total node degree (the number of incoming and outgoing, does not include self-burning) was 3.84 , with 39 nodes, 75 edges, and a network density of 0.05 . The diagram suggests a relatively high level of fire exchange between private lands and national forests. State lands exchanged fire mainly with the Coronado NF, Tonto NF, and Apache-Sitgreaves NF, and received substantial fire from BLM lands. Finally, tribal lands exchanged fire with other BLM lands and with the Tonto and Apache-Sitgreaves NFs.

\subsection{Fire Transmitted into Communities}

As described in the methods Section 2, our definition of communities included the community or city boundary as described in the U.S. Census Bureau (U.S. Census Bureau, 2016) plus associated WUI polygons. Communities received $7.1 \%$ of all transmitted wildfire between land tenures $(2,404$ ha per year), whereas nontransmitted fire for communities accounted for $1.3 \%$ of the total (755 ha per year; Table IV). Annual structure exposure to communities from all other tenures was 2,675 housing units (not considering transmission between communities). State and FS-M lands were the major contributors of wildfire exposure as measured by structures affected, 
Table IV. Transboundary Wildfire Transmission Among the Major Land Tenures in Arizona

\begin{tabular}{|c|c|c|c|c|c|c|}
\hline Land Tenure & $\begin{array}{l}\text { Total Area } \\
\text { Burned } \\
\text { (ha/year) }\end{array}$ & $\begin{array}{l}\text { TF-IN } \\
\text { (ha/year) }\end{array}$ & $\begin{array}{l}\text { Non-TF } \\
\text { (ha/year) }\end{array}$ & $\begin{array}{l}\text { TF-OUT } \\
\text { (ha/year) }\end{array}$ & $\begin{array}{l}\text { Transmitted Fire to } \\
\text { Communities (\% of } \\
\text { total incoming) }\end{array}$ & $\begin{array}{l}\text { Percent of Outgoing } \\
\text { Fire that Reaches } \\
\text { Communities }\end{array}$ \\
\hline BLM & 19,221 & $\begin{array}{c}5,029 \\
(26.2 \%)\end{array}$ & 14,192 & 5,353 & 9.6 & 4.32 \\
\hline FS-M & 18,824 & $\begin{array}{c}5,284 \\
(28.1 \%)\end{array}$ & 13,540 & 5,866 & 19.5 & 7.98 \\
\hline State & 13,136 & $\begin{array}{c}7,020 \\
(53.4 \%)\end{array}$ & 6,116 & 6,172 & 15.4 & 6.00 \\
\hline Tribal & 14,035 & $\begin{array}{c}2,338 \\
(16.7 \%)\end{array}$ & 11,697 & 2,430 & 10.5 & 10.41 \\
\hline Private & 13,582 & $\begin{array}{c}8,000 \\
(58.9 \%)\end{array}$ & 5,582 & 7,235 & 36.7 & 12.19 \\
\hline FS-P & 5,083 & $\begin{array}{c}2,178 \\
(42.8 \%)\end{array}$ & 2,905 & 2,449 & 3.0 & 2.99 \\
\hline Community & 3,159 & $\begin{array}{c}2,404 \\
(76.1 \%)\end{array}$ & 755 & 2,366 & - & - \\
\hline NPS & 1,480 & $\begin{array}{c}523 \\
(35.3 \%)\end{array}$ & 957 & 657 & 1.6 & 5.99 \\
\hline $\mathrm{DOD} / \mathrm{DOE}$ & 794 & $\begin{array}{c}136 \\
(17.1 \%)\end{array}$ & 658 & 223 & 0.1 & 1.08 \\
\hline FWS & 740 & $\begin{array}{c}127 \\
(17.2 \%)\end{array}$ & 613 & 218 & 0.1 & 1.00 \\
\hline Public & 550 & $\begin{array}{c}412 \\
(74.9 \%)\end{array}$ & 138 & 426 & 2.4 & 13.47 \\
\hline ARS & 300 & $\begin{array}{c}165 \\
(55 \%)\end{array}$ & 135 & 170 & 1.0 & 13.76 \\
\hline BOR & 160 & $\begin{array}{c}119 \\
(74.4 \%)\end{array}$ & 41 & 170 & 0.1 & 1.29 \\
\hline
\end{tabular}

Notes: Total area burned includes TF-IN + non-TF. Non-TF $=$ the annual area of nontransmitted fire (self-burning). TF-IN $=$ the annual area burned from incoming fires ignited on other land tenures. TF-OUT $=$ the annual area burned on other land tenures by fires ignited locally. Total incoming fire represents the same amount as total outgoing fire ( $\Sigma$ TF-IN $=\Sigma$ TF-OUT $=33,735$ ha). Numbers in parentheses in TF-IN denote the percentage of TF-IN from the amount of total area burned. See Table II for land tenure descriptions.

followed by tribal, private, and BLM (Fig. 6), a trend that mostly correlated with annual area of wildfire transmitted to communities. Except for private lands, where the ratio of structures affected to area burned by fire transmitted to communities was below $1(0.5)$, all other land tenures had a ratio greater than 1 , with the highest value for public (2.7), DOD/DOE (2.6), and tribal lands (Radeloff et al., 2005).

The 447 communities were ranked in order of incoming fire exposure based on area burned (top 50; Fig. 7). The annual area burned within each community from fires ignited on adjacent land tenures varied from a low of 0.1 ha (Buckshot, small community in the very southwest corner of the state) to 157 ha (Buckeye, west of Phoenix). The majority of communities received fire from FS lands that can be managed with mechanical treatments based on forest plan guidelines (e.g., Sierra Vista, Mayer, Valle), although a few received substantial fire from FS lands that cannot be managed (FS-P, e.g., Sierra Vista Southeast, Camp Verde). About five communities had the majority of the annual area burned coming from the BLM (Buckeye, Goodyear, Littlefield, Avra Valley, Dolan Springs, and Picture Rocks), whereas more than 10 communities had substantial fire coming from state lands. Private lands contributed largely to wildfire transmission to high population communities such as Buckeye, Tucson, and Sierra Vista.

The annual structures predicted to be exposed to fire was 6,698 and varied by community (range 1,273 for Phoenix to nearly 0 for Hard Rock). In total, 3,717 structures per year were affected by incoming fires (all land tenures including transcommunity exposure) and 2,981 structures per year from nontransmitting fires. The largest exposure from incoming fires was estimated for Tucson (485), followed by Phoenix (376) and Scottsdale (120), with the remaining communities having exposure of less 
Fig. 3. Relationship between the total amount of transboundary wildfire among large land tenures in Arizona and average parcel size. Points are sized by the number of parcels. See Table II for land tenure descriptions.



Fig. 4. Major transboundary wildfire transmission pathways among land tenures in Arizona. Nontransmitted wildfire (self-burning) is not shown. Arrow width represents the amount of fire exchange at three scales $(<500,500-1,000$, $>1,000$ ha/year). Node size represents the sum of incoming and outgoing fire at three scales $(<4,000,4,000-10,000,>10,000$ ha/year $)$. Network is filtered to show transmission of $>60$ ha/year. Orange nodes represent communities. See Table II for land tenure descriptions.

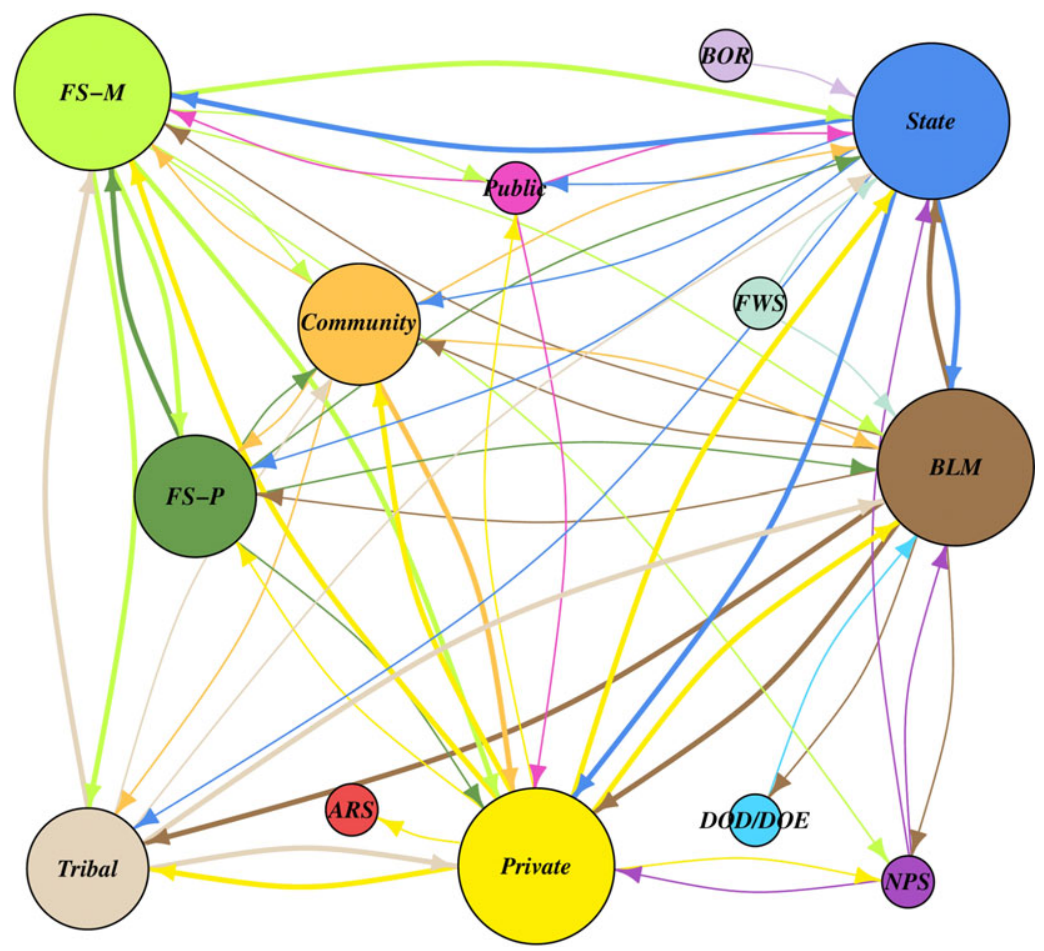

than 100 structures per year (Fig. 8). The bulk of exposure was created by other communities or state lands, although high exposure from FS lands and the BLM was estimated for a subset of communities.

The wildfire transmission network of major land tenures and Arizona's top 60 exposed communities (Fig. 9) revealed that most communities were linked to FS-M, BLM, tribal, and state lands. Protected
FS lands, NPS, DOD/DOE, and public lands had low node degree and wildfire transmission to communities. Note that the network is filtered to retain only substantial wildfire transmission (edge strength $>15$ ha per year). The average total degree for the network was 5.31, with 70 nodes, 186 edges, and a network density of 0.04 ( $4 \%$ of all possible linkages between land tenures and individual communities 


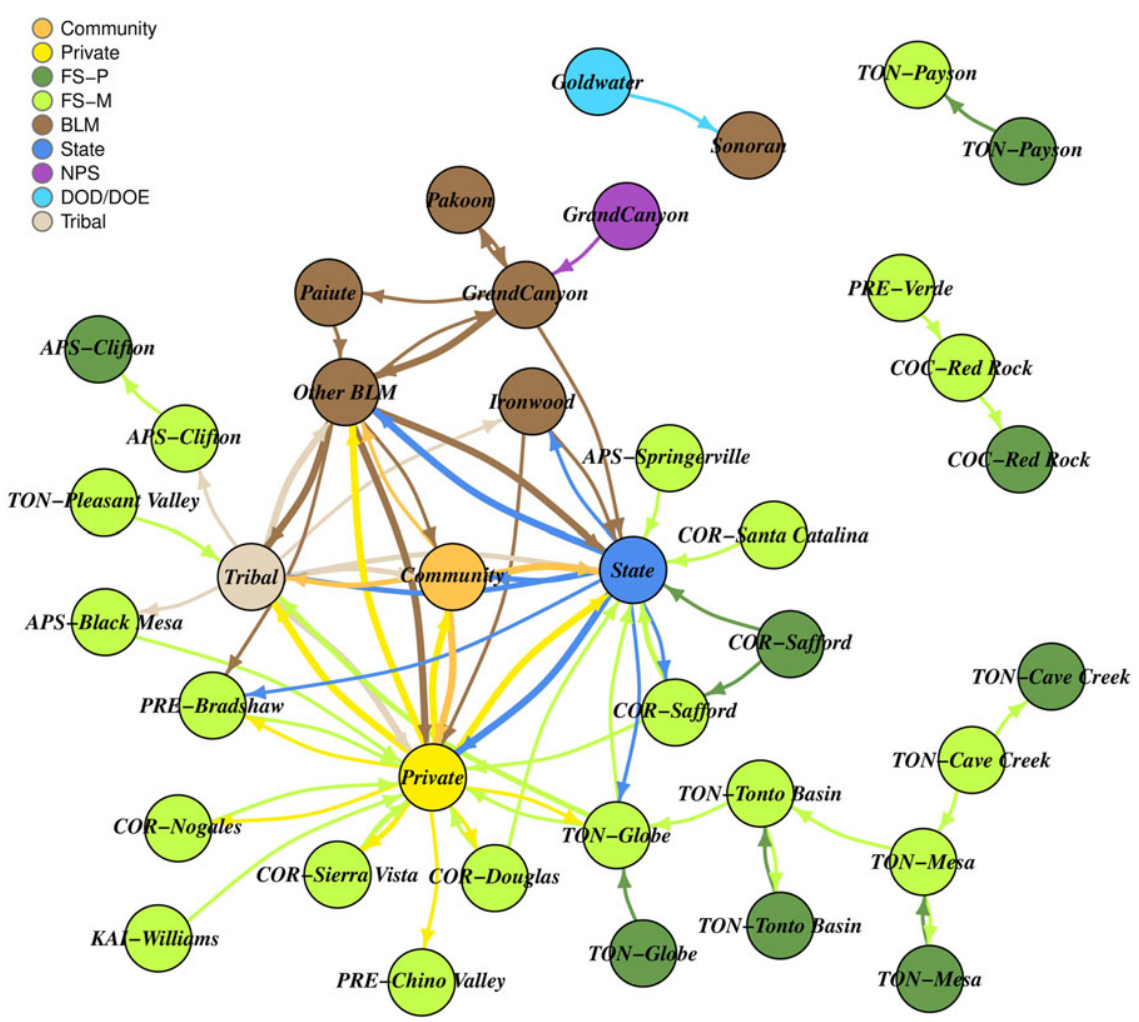

Fig. 5. Transboundary wildfire transmission among major land tenures and national forest (NF) ranger districts and Bureau of Land Management (BLM) districts. Nontransmitted wildfire (self-burning) is not shown. Arrow width is colored by its source and represents the amount of fire exchange at three scales $(<500,500-1,000,>1,000$ ha/year). Network is filtered to show transmission of $>80$ ha/year. COR, Coronado NF; PRE, Prescott NF; TON, Tonto NF; APS, Apache-Sitgreaves NF; COC, Coconino NF. See Table II for land tenure descriptions.

was present). Connectivity of individual nodes in the land tenure network varied from a low of 1 to a high of 9. For instance, Alamo Lake and Meadview had only one connection, whereas Three Points had five and Tucson had nine. Of the major land tenures, state had 47 connections, followed by FS-M (Scott et al., 2013) and BLM (Miller \& Ager, 2013).

Transmission of fire to communities varied in terms of the amount and relative contribution of the sources (Fig. 10). Communities receiving more fire had higher node degree (more neighbors). At the most, 31 different land tenures/communities transmitted fire to communities such as Tucson or Phoenix, whereas other communities had a single contributor (e.g., Burnside or Shonto). The positive relationship between total fire received and number of land tenures was partly caused by the fact that larger communities received more fire than smaller communities as they have more neighbors. However, exceptions to the trend are evident, with some communities having a high number of neighbors con- tributing fire (e.g., San Tan Valley) for a low amount of fire exposure. Thus, two communities with a given amount of fire exposure may or may not require collaborative planning to reduce wildfire risk.

\subsection{Firesheds}

We found that firesheds-i.e., lands likely to contribute wildfire exposure to structures, including populated places and WUI-constituted 7.7 million ha, or $26 \%$ percent of the study area (Fig. 11; Table V). Thus firesheds on average were about 3.2 times larger than the communities as defined in the study (populated place boundary plus surrounding WUI) and 3.5 times larger than the populated places alone. Excluding the communities, firesheds were comprised of FS-M (24\%), private (19\%), tribal (17\%), BLM $(17 \%)$, and state lands $(15 \%)$ (Table V). The dominant fuel model types over the entire fireshed were grass-shrub (GS1 and GS2), covering half of the fireshed $(50.6 \%)$, followed by grass (GR1 and 
Fig. 6. Total wildfire exposure to communities by land tenure measured as total area burned and structures affected annually. "Other Fed." refers to the sum of values for the following federal landowners: ARS, BOR, and FWS. See Table II for land tenure descriptions.

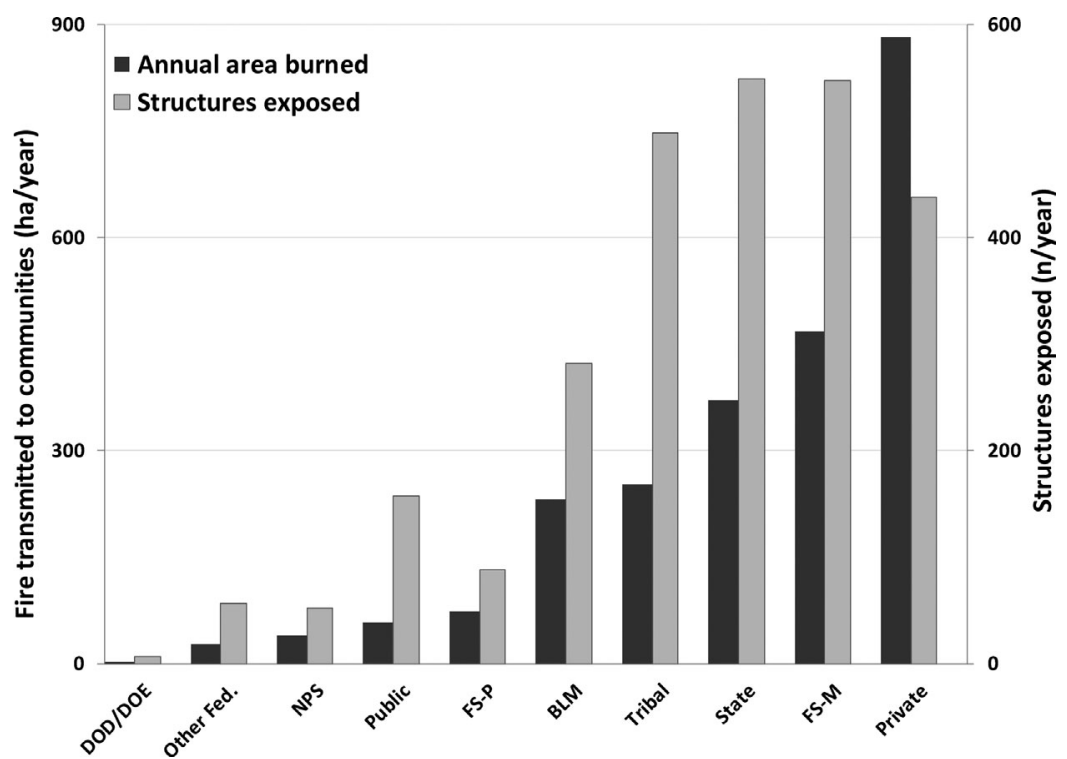

GR2, 21.4\%), shrub (SH1, SH7, and SH5, 12.5\%), and timber litter (TL8 and TL3, 5.4\%). Communities were comprised of grass-shrub, nonburnable, and grass fuel models (Table V).

\subsection{Scale and Composition of Wildfire Exposure}

We quantified and mapped the scale of wildfire exposure in the study area with six indices as described in Section 2.7. The map of SFCI revealed locations that were affected (received fire) by ignitions on a relatively large number of land tenures (Fig. 12a). Areas affected by many land tenures have a higher complexity in terms of collaborative management of landscape fuels and suppression strategies. The highest SFCI values were observed around the Safford and Globe RDs and close to the cities of Picture Rocks, Dudleyville, and Globe (Figs. $1 \mathrm{~b}$ and $12 \mathrm{a}$ ). Areas with highest complexity tended to coincide with community fireshed boundaries located outside of FS lands. The FSAI (Fig. 12b) indicated the average size of the fire that burned each pixel, with the highest values in central Arizona, inside the Mogollon, Williams, Mormon Lake, Peaks, Lakeside and Black Mesa RDs. Higher values of the IDI (Fig. $12 \mathrm{c}$ ), which measured the average distance wildfire spread to each SILVIS WUI polygon weighted by the number of structures exposed, were located on tribal lands south of Apach-Sitgreaves NF, and the Juniper Mountains close to Flagstaff. The FSPI (Fig. 12d) identified locations that generated the largest fires, with the highest values observed for
FS RDs in central and northern Arizona. The SEI estimated the annual number of structures exposed per pixel from a given ignition source (Fig. 12e). Values for SEI were highest for the communities affected by the Apache-Sitgreaves NF in the central eastern part of the state, including the communities of Show Low, Pinetop Country Club, and Wagon Wheel. High SEI values were also observed on portions of the Prescott and Coconino NFs. The SBI (Fig. 12f) showed the percentage of self-burning versus incoming fire for each pixel. High values were estimated for areas across the state, with national forests containing areas with high values.

\section{DISCUSSION}

\subsection{Comparison to Existing Risk Assessment Methods}

We introduce a number of newer risk concepts and metrics related to large wildland fires that are useful for "all lands" fire management on landscapes that are highly fragmented with respect to land tenures and fire ecology (Table I). Parcel geometry and relative sizes of different ownerships set the stage for fire transmission across boundaries (Ager et al., 2017). Although we have focused on wildfire exposure (SRA, 2013), all of the concepts and metrics could be formulated as risk as well (Finney, 2005). However, estimating fire effects on structure values is difficult with landscape scale fire modeling (Alcasena, Salis, Ager, Castell, \& Vega-Garcia, 
(a)

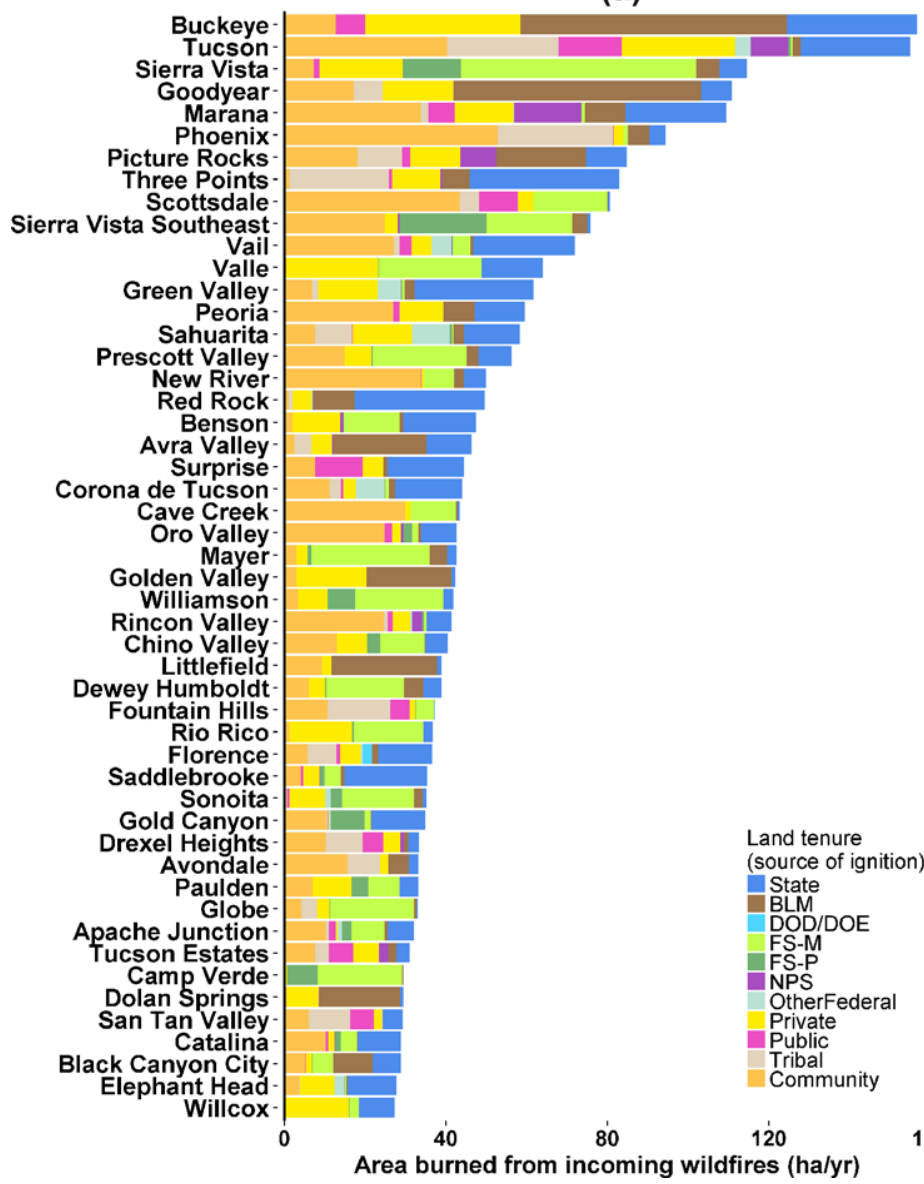

(b)

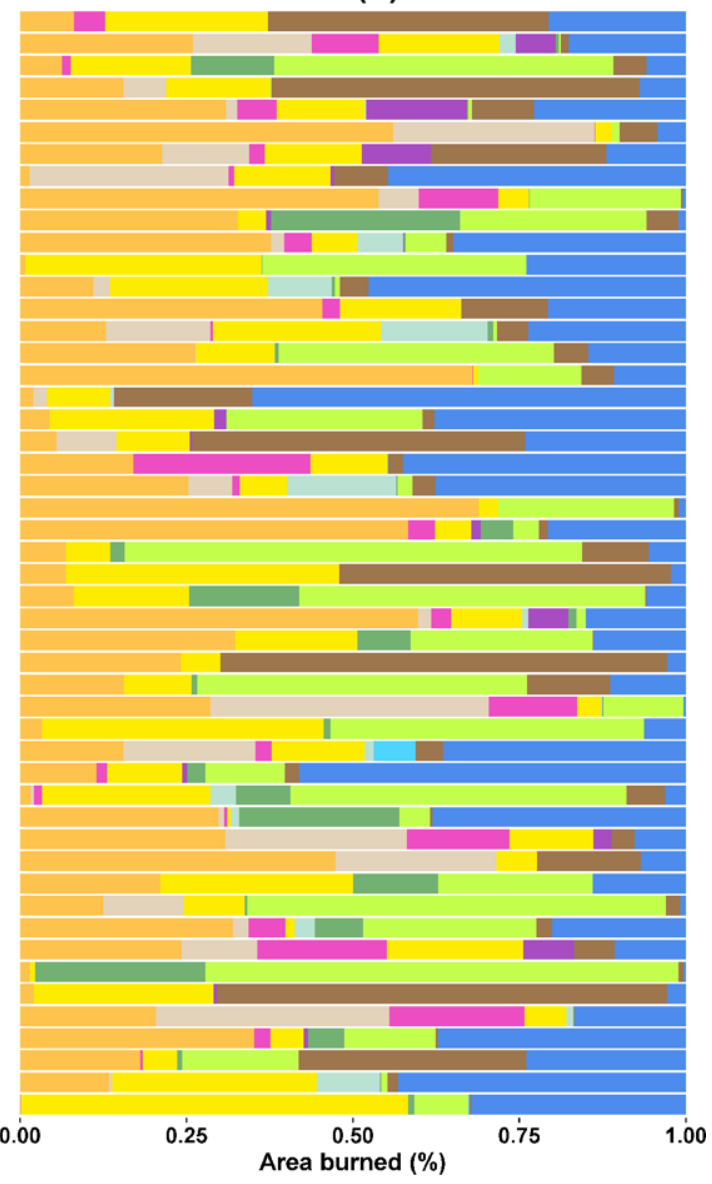

Fig. 7. Predicted annual area burned within communities from wildfires ignited elsewhere by source of ignition (a) and percent composition (b) for each community. Graph was filtered to show the top 50 out of 447 communities identified in the study area.

2017). Incorporating the sources of transboundary risk into risk assessments (Renn et al., 2011; van Asselt \& Renn, 2011) has been advocated in the broader risk governance literature. Fine tuning risk governance that specifically factors transboundary risk requires explicit consideration of our concepts and metrics to account for the scale at which wildfire exposure is propagated among and within the land parcels. The metrics we calculated address scale and tenure composition of both incoming and outgoing fires for a given location (Fig. 12). Our methods characterize risk at the scale of fire events, rather than in situ conditions on a given parcel, and provide quantitative information to engage and initiate dialogues about transboundary wildfire risk governance.

Fire regimes and land development patterns in Arizona are replicated in much of the western United States, and thus our methods can be extrap- olated to other states to address similar challenges faced by agencies attempting to coordinate mitigation activities (Fernandes, Botelho, \& Loureiro, 2002; NFPA, 2015). Existing risk assessment methods either do not consider risk from large fires, and/or they fail to communicate risk as a disturbance process that spans parcels of land owned or managed by different public agencies and private entities. This gap can contribute to poor risk perception and reduced motivation to address wildfire issues (Fischer, Kline, Ager, Charnley, \& Olsen, 2014). State land management agencies in the western United States use WRAPS (Arizona State Forestry, 2016) to communicate wildfire risk information and generate awareness about wildfire issues across the state to support mitigation and prevention efforts. The system was chartered by the Council of Western 
(a)

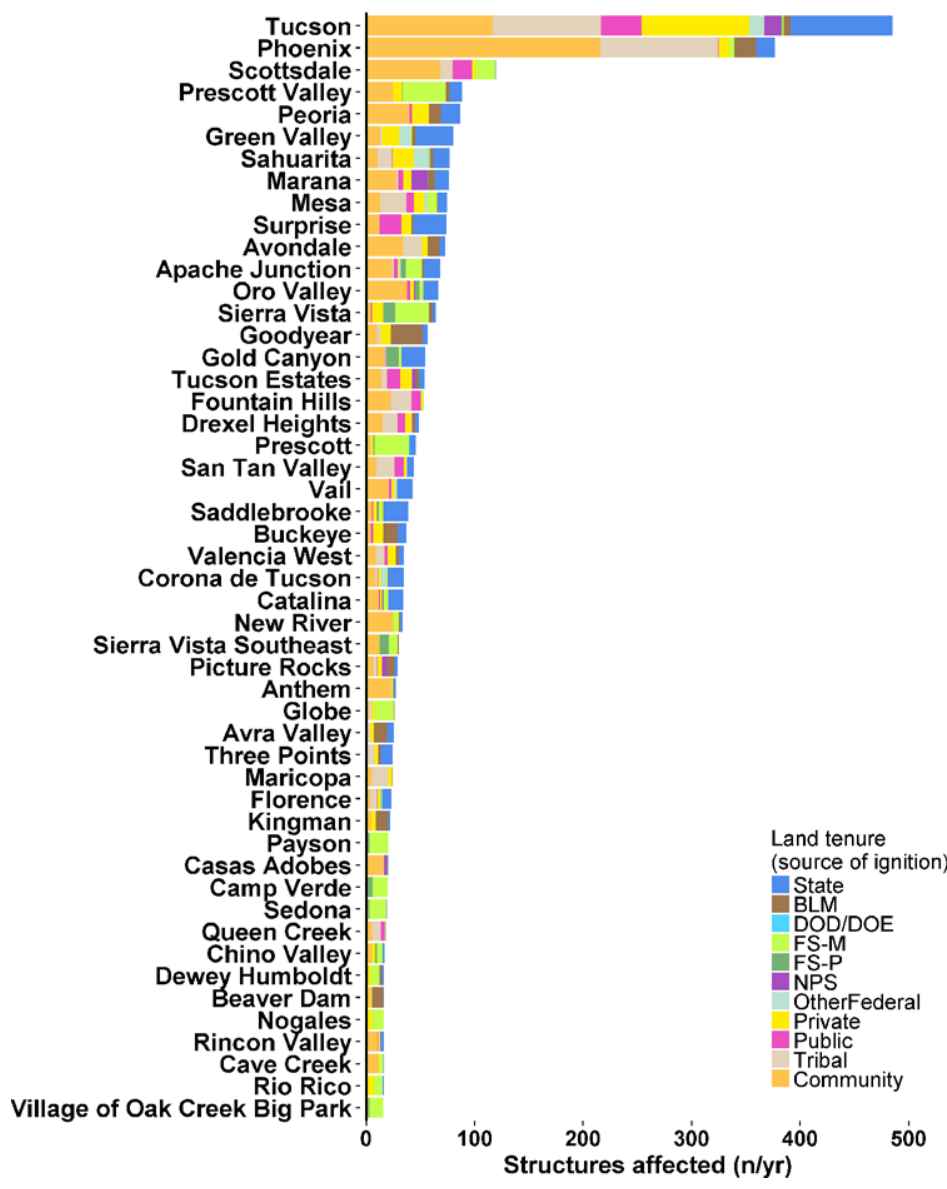

(b)

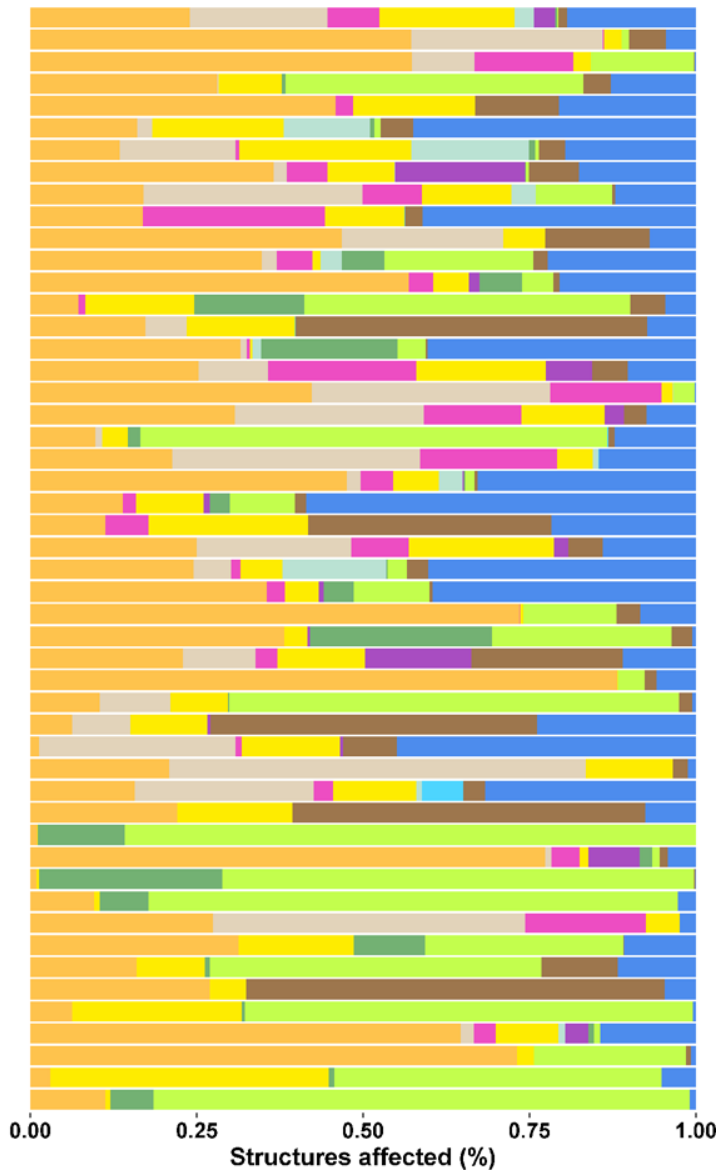

Fig. 8. Predicted structures affected annually by incoming fire by land tenure source (a) and percent of total exposure for each community (b). Graph was filtered to show the top 50 communities out of 447 identified in the study area.

Foresters and the Western Forests Leadership Coalition. The utility of the WRAPS portal in Arizona (AZWRAPS) has been burdened by the complexity of the inputs and composite indices (personal communication, Arizona State Forester's Office) and the system does not use terminology consistent with that established in the risk science community (SRA, 2013). The core geospatial data were developed as part of the West Wide Wildfire Assessment covering the 17 western states (WWWRA, 2013a). The underlying modeling effort considered highly valued resources and susceptibility, but relied on ignition probability maps to predict fire occurrence and local cell-based spread rates to evaluate fire propagation. This approach underestimates the local impacts of long-distance fire spread from large fires, as pointed out in several prior studies (Miller \& Ager, 2013).
Moreover, the use of empirical ignitions as a proxy for burn probability has a number of limitations. First, empirical ignition maps show where fires have recently burned, and thus one might expect lower risk in these areas depending on the fuels and vegetation type and the fire intensity. None of these factors is considered in the state risk assessment, and ignition maps might actually show where risk is lowest since frequent fires might well deplete fuels. Second, ignition maps have little information in terms of what was actually affected by the fire compared to our transmission metrics (Fig. 12) that measure the spatial scale of exposure from fire events. Third, from the risk management standpoint, it is important to partition human versus natural ignitions as the source of exposure (Ager et al., 2017) since managing these different ignition sources involves vastly different risk problems. Partitioning 


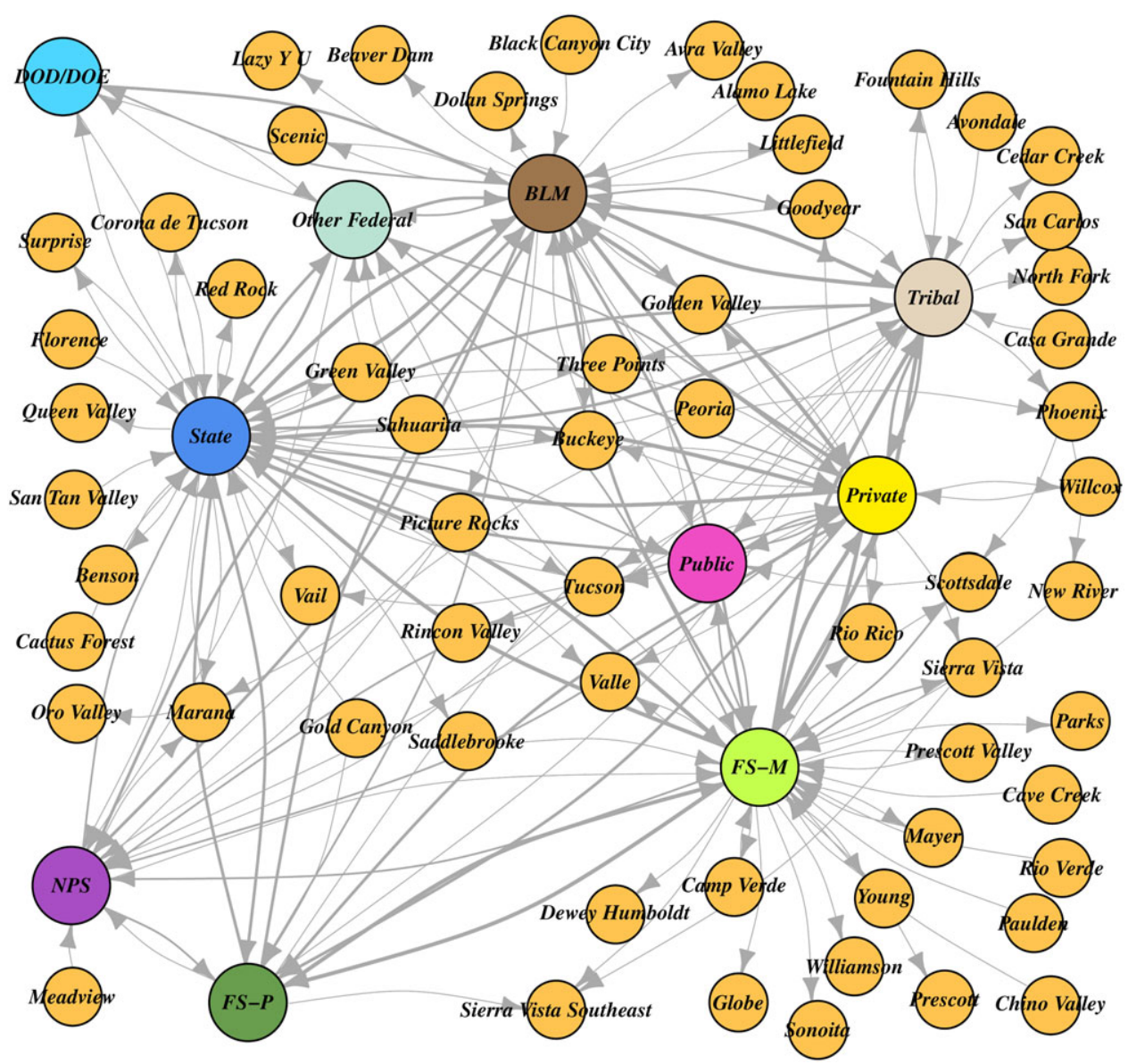

Fig. 9. Network diagram showing transboundary wildfire transmission between major land tenures and communities. Nontransmitted wildfire (self-burning) is not shown. Arrow width represents the amount of fire exchange at three scales $(<50,50-100,>100$ ha/year). Network is filtered to show transmission of $>15 \mathrm{ha} /$ year. Orange nodes represent communities. See Table II for land tenure descriptions.

human versus natural ignitions was not possible in the simulations, although we demonstrated the significance of the different sources of ignitions on risk transmission in prior work (Ager et al., 2017). Regional differences in the proportion of human versus natural ignitions is substantial in the western United States (Balch et al., 2017; Parisien et al., 2016).

Finally, one could argue that there is higher risk in areas with no ignitions since these areas have not burned in recent times. WRAPS does use empirical ignition maps in a GIS smoothing process to generate burn probability maps. These data include all ignitions, the vast majority of which are small backyard fires that are immediately suppressed. From an urban and county-level fire suppression standpoint, risk maps based on ignition probability can be useful for responding to human-caused fires and developing prevention programs. However, the maps do not contribute to understanding the likelihood of a pixel burning from a large destructive wildfire that ignites on some distant landscape, causing the majority of private property damage. Moreover, analysis of ignition probabilities precludes an analysis of who owns the risk and who is transmitting it among landowner parcels. For instance, designing mitigation strategies requires that public land management agencies, including the Forest Service, understand how alternative fuel management strategies can change WUI exposure to wildfires. The core methods used in the state WRAPS preclude these types of analyses since wildfire paths cannot be traced to the origin (i.e., all risk is driven by local estimates). Thus information on the scale of risk cannot be derived from these risk assessments since local pixel-based calculations of spread rates do not connect ignition sources with the final perimeter. Without adopting a completely 


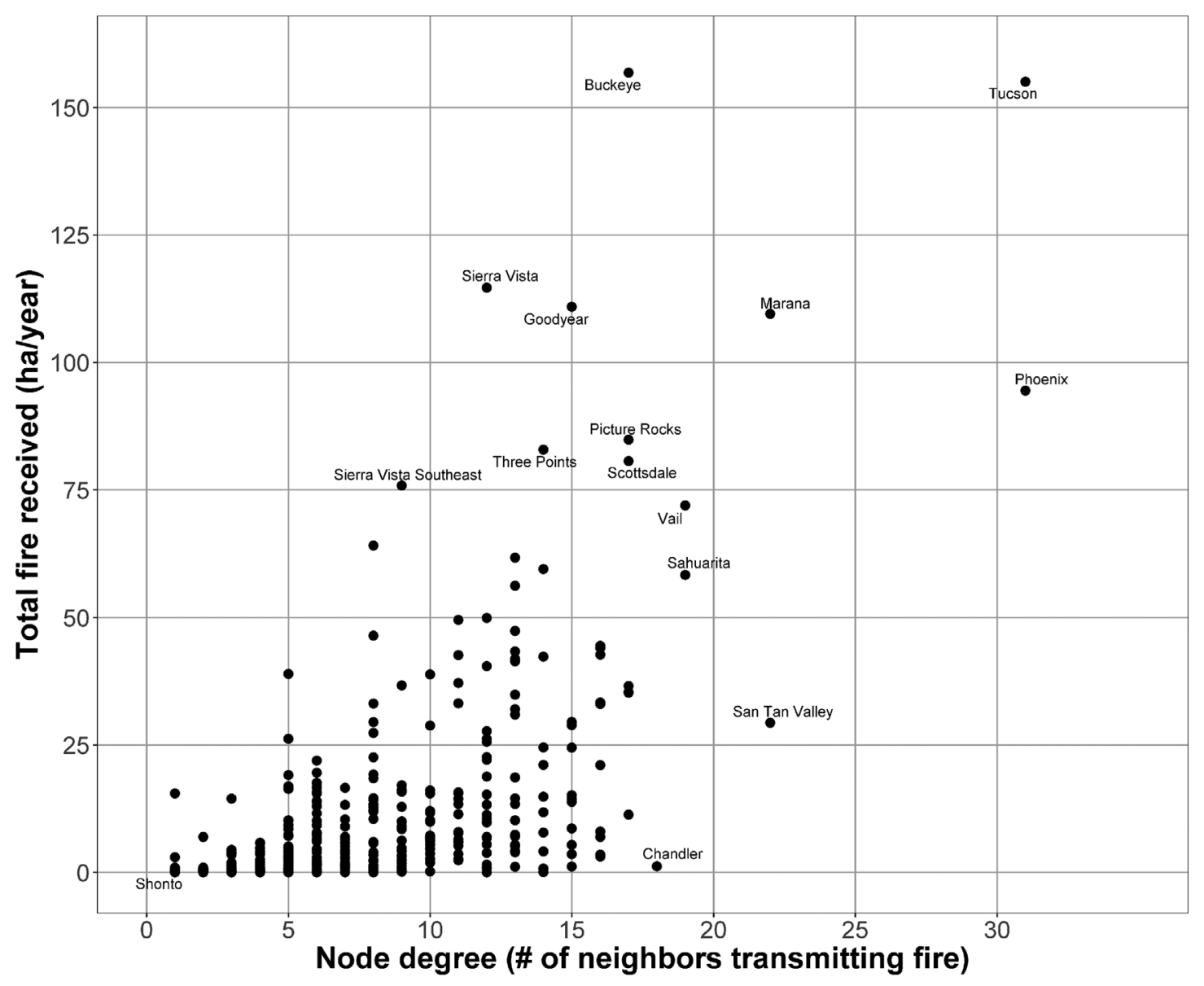

Fig. 10. Relationship between the number of land tenures contributing wildfire to individual communities and the total area burned within communities from fires ignited elsewhere.

different approach to estimating wildfire burn probability, the state assessments have little value as far as informing where and how fuel treatments can be used to reduce risk from large wildfires. Federal land managers will have a difficult time using the WRAPS to design and test landscape coordinated fuel management strategies (Collins et al., 2010) because the change in risk will only be observed in the treated pixels in contrast to landscape-scale reductions in fire spread and intensity. Another limitation of the WRAPS in terms of a comprehensive fire management strategy is that risk mapping methods are needed to design and test landscape fuel treatment strategies to complement managing unplanned ignitions as part of a systematic policy to reduce fuel loadings on fire excluded landscapes. Developing these strategies is best informed by large fire simulation methods that can be used to predict large fire impacts.

\subsection{Mitigating Transboundary Risk in Fuel Management Programs}

Efficient implementation of "all lands" wildfire mitigation will require a clear understanding of who owns wildfire risk and the relative risk interactions among landowners. The challenge for land managers is to organize landscape fuel treatments that couple the biophysical aspects of fire occurrence and spread with the social component of landowners' propensity to act to treat fuels (Fischer et al., 2014). In this way, conflicts and opportunities to achieve federal wildland fire policy, including fire-adapted communities, fire-resilient landscapes, and wildfire response (USDA-USDI, 2013), can be identified and mapped to facilitate implementation of policies that will inform risk governance at the proper scale.

In the specific case of fuel management on western U.S. national forests, current programs are 


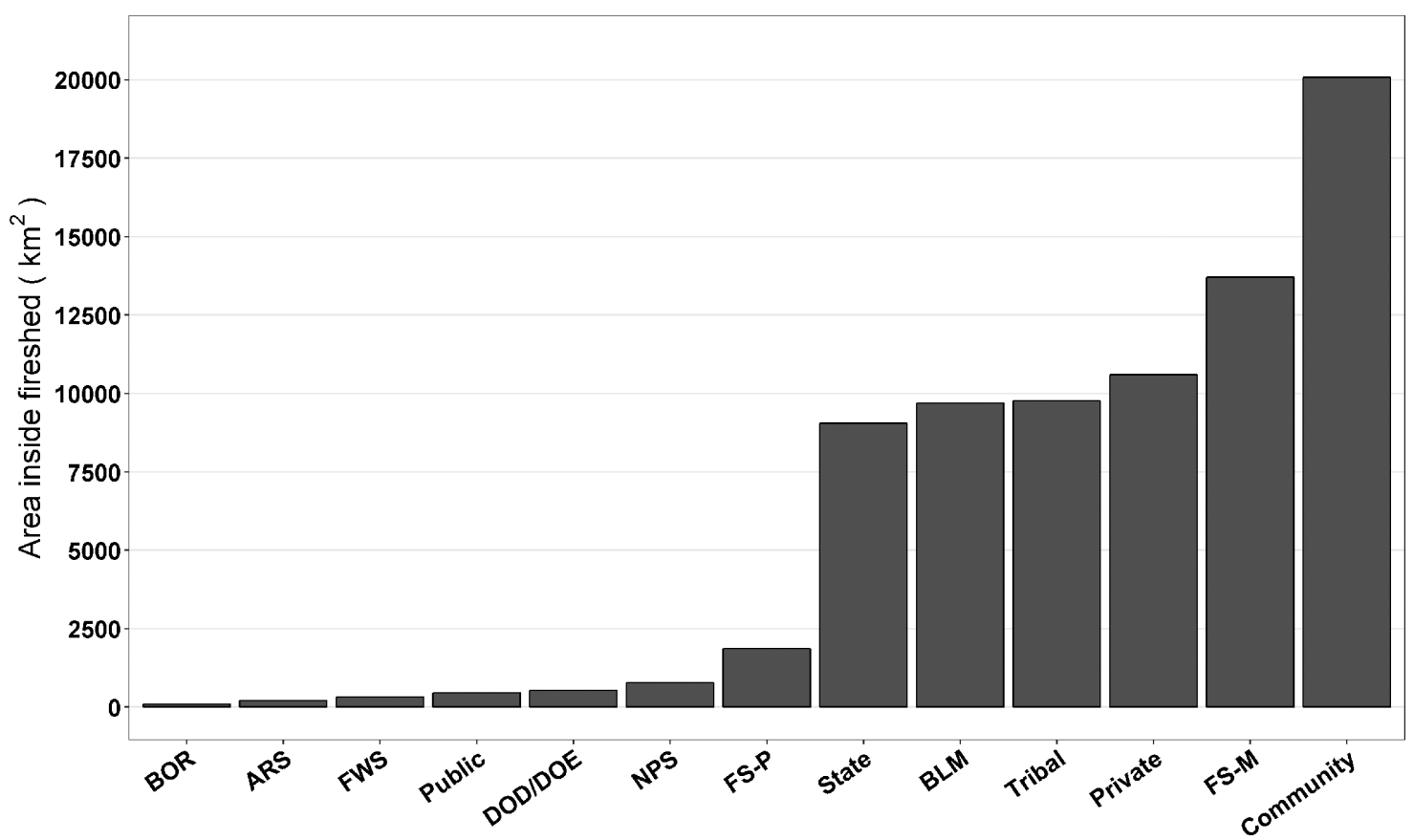

Fig. 11. Fireshed area by land tenure showing the relative contributions of different land tenures to community exposure. See Table II for land tenure descriptions.

Table V. Fireshed Composition by Fire Behavior Fuel Model Type and Land Tenure

\begin{tabular}{|c|c|c|c|c|c|c|c|c|}
\hline \multirow[b]{2}{*}{ Land Tenure } & \multicolumn{2}{|c|}{ Area in Fireshed } & \multicolumn{6}{|c|}{ Fuel Model Type (\%) } \\
\hline & ha & $\%$ & Grass & Grass-Shrub & Shrub & Timber Understory & Timber Litter & Nonburnable \\
\hline Community & $2,007,996$ & 26.02 & 14 & 46 & 10 & 1 & 2 & 27 \\
\hline FS-M & $1,370,415$ & 17.76 & 35 & 40 & 8 & 2 & 14 & 1 \\
\hline Private & $1,059,890$ & 13.74 & 27 & 44 & 13 & 0 & 1 & 15 \\
\hline Tribal & 976,700 & 12.66 & 11 & 65 & 11 & 2 & 6 & 5 \\
\hline BLM & 969,821 & 12.57 & 11 & 72 & 14 & 0 & 0 & 3 \\
\hline State & 904,603 & 11.72 & 21 & 60 & 15 & 0 & 0 & 4 \\
\hline FS-P & 185,828 & 2.41 & 23 & 50 & 11 & 2 & 9 & 5 \\
\hline NPS & 78,170 & 1.01 & 16 & 64 & 12 & 1 & 1 & 6 \\
\hline DOE & 54,069 & 0.70 & 10 & 32 & 29 & 1 & 5 & 23 \\
\hline Public & 45,380 & 0.59 & 4 & 89 & 5 & 0 & 0 & 2 \\
\hline FWS & 32,689 & 0.42 & 8 & 80 & 9 & 1 & 0 & 2 \\
\hline ARS & 21,411 & 0.28 & 10 & 74 & 16 & 0 & 0 & 0 \\
\hline BOR & 9,409 & 0.12 & 8 & 36 & 40 & 0 & 0 & 16 \\
\hline
\end{tabular}

Notes: See Table II for land tenure descriptions. Fuel models are based on Scott and Burgan (2005). Firesheds are defined as lands likely to contribute wildfire exposure to structures, including populated places and the wildland urban interface.

highly motivated by transboundary issues, especially wildfire transmission to the WUI (USDA-USDI, 2001). However, evaluation of fuel treatment strategies for transboundary risk has been largely ignored in several recent reviews (Kalies \& Yocom Kent, 2016; Vaillant \& Reinhardt, 2017). This gap is significant because transboundary risk constrains fire protection and restoration goals in areas fragmented by jurisdictions, ownerships, and fire regimes. For instance, fire-adapted lands near land tenure boundaries where transmission risk is generally high will not be maintained with natural ignitions, and thus mechanical treatments and prescribed fire must be emphasized in these areas. Optimizing the combined effect of mechanical forest fuel treatments and restoration wildfires at the landscape scale to meet 
Fig. 12. Metrics to illustrate the spatial scale, tenure composition, and structure exposure of transmitted wildfire. (a) Source fire complexity index (SFCI); (b) fire size arrival index (FSAI); (c) ignition distance index (IDI); (d) fire size potential index (FSPI); (e) structure exposure index (SEI); (f) self-burning index (SBI).
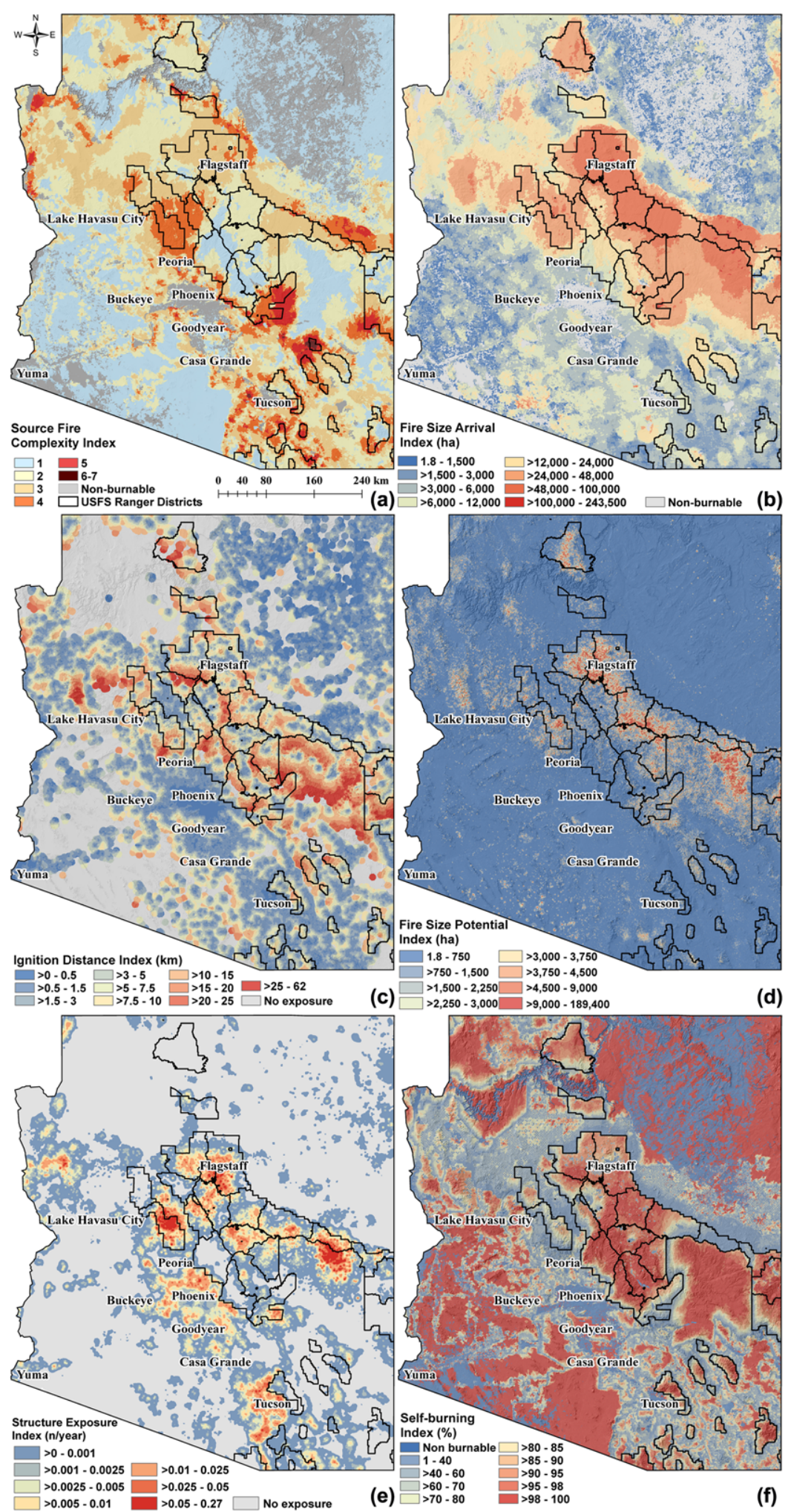
socioeconomic and ecological goals of federal forest restoration programs will require mapping protection versus restoration of fire, considering the juxtaposition of fire regimes and socioecological values.

In terms of project-specific strategies for mitigating transboundary risk, past research on fuel treatment optimization with wildfire simulation modeling (Finney, 2001, 2007) has revealed how patterns of treatment units, their orientation, and shape can be optimized to reduce fire spread in particular directions. These concepts can be applied to transboundary risk where fuel treatment units are optimized to reduce fire spread along vectors that most contribute to transboundary fire. Simulation outputs identify transmission paths (e.g., Fig. 9) that can be mitigated with the treatment optimization model (Finney, 2006) to identify optimal treatment locations to reduce fire spread in those specific directions.

\subsection{Networks for Communicating Risk}

As pointed out in other studies (Ager et al., 2017; Bodin, Crona, \& Ernstson, 2006; Fischer, Vance-Borland, Jasny, Grimm, \& Charnley, 2016), network methods can inform landscape planning for restoration, biodiversity conservation, and fire protection efforts in a number of ways. In this study, network analysis of simulation outputs provided an analytical framework to disentangle transmission on a large fragmented landscape and visualize landscape fire connectivity. Fire networks describe where collaborative networks among institutions and landowners are most needed to facilitate transboundary planning (Fischer et al., 2016) to coordinate wildfire management, whether it be the design of fuel break systems for community wildfire protection, or managing wildfires as fuel treatments in fire-adapted forests. Network metrics, including node degree, network density, transmission ratios, and transmitted fire, describe the typology of fire transmission on fragmented landscapes. This information can be used to balance investment in restoration of fire-adapted landscapes with efforts to protect communities from wildfires. For instance, from a fire suppression standpoint, a high node degree for a private land designation would indicate a risk liability to other public and private parcels in the network. Similarly, fuels management activities on lands with high values of incoming transmission will likely not reduce the likelihood of a fire arriving from another designation, and fuel management activities need to target nodes in the network that are responsible for large fire transmission.

\subsection{Application to WUI Protection Planning}

Our transboundary assessment methods have multiple applications for community protection planning. Transmission networks could be used to provide explicit identification of the sources of wildfire exposure and the responsible landowners. The fireshed encloses the sources of ignitions transmitting fire to communities, thus identifying the relevant planning area from a biophysical risk standpoint for community protection planning. This approach is in contrast to the current community wildfire protection planning (CWPP) guidelines (CWPP Task Force, 2014), where perimeters are typically based on administrative boundaries (Jakes et al., 2011). The lack of a spatial planning framework for the CWPP process has led to a wide range of planning scales (e.g., neighborhoods, towns, multiple towns, entire counties) and associated boundary delineations that are potentially unrelated to the spatial extent of fire transmission to communities. This type of scale mismatch between planning boundaries and the ecological pattern or process relevant to the conservation or protection problem has been widely discussed (Cumming et al., 2006; Guerrero, McAllister, Corcoran, \& Wilson, 2013; Sarkar et al., 2006). Our analysis inherently connects landscapes and represents exposure as a process among land parcels rather than a property of the parcel. Because landscape fragmentation within public lands and on private lands is at a fraction of the scale of large wildfire events, the importance of the landscape overshadows the properties of individual parcels in terms of risk. Although this is incorporated in risk assessments that use burn probability, it is not possible to disentangle the spatial scale of risk and the relative contributors to different parcels. Moreover, the merging of largescale risk assessment products (Calkin, Thompson, Finney, \& Hyde, 2011) with the CWPP process as part of an all lands approach has not been discussed.

\section{ACKNOWLEDGMENTS}

This work was initiated as part of the Arizona Landscape Restoration Partnership, a collaborative effort among the state of Arizona, USDA Forest Service, and Northern Arizona State University. We thank Karen Short for making wildfire simulation 
data available. We also thank Jeff Whitney, Arizona State Forester, for many helpful discussions about wildfire and restoration issues in the state of Arizona. Glen Buetner, Diane Vosick, and Amy Waltz all contributed to the dialog about improving methods for understanding transboundary risk. Ken Bunzel provided GIS processing of FSim outputs and calculation of transmission statistics. We also thank two anonymous reviewers.

\section{REFERENCES}

Ager, A. A., Bahro, B., \& Barber, K. (2006). Automating the fireshed assessment process with ArcGIS. In P. L. Andrews \& B. Butler (Eds.), Fuels management-How to measure success (pp. 163-168). Proceedings RMRS-P-41, 28-30 March 2006. Fort Collins, CO: USDA Forest Service, Rocky Mountain Research Station.

Ager, A. A., Day, M. A., Finney, M. A., Vance-Borland, K., \& Vaillant, N. M. (2014). Analyzing the transmission of wildfire exposure on a fire-prone landscape in Oregon, USA. Forest Ecology and Management, 334, 377-390.

Ager, A. A., Day, M. A., McHugh, C. W., Short, K., GilbertsonDay, J., Finney, M. A., \& Calkin, D. E. (2014). Wildfire exposure and fuel management on western US national forests. Journal of Environmental Management, 145, 54-70.

Ager, A. A., Day, M. A., Short, K. C., \& Evers, C. R. (2016). Assessing the impacts of federal forest planning on wildfire risk mitigation in the Pacific Northwest, USA. Landscape and Urban Planning, 147, 1-17.

Ager, A. A., Evers, C. R., Day, M. A., Preisler, H. K., Barros, A. M., \& Nielsen-Pincus, M. (2017). Network analysis of wildfire transmission and implications for risk governance. PLoS ONE, 12(3), e0172867.

Ager, A. A., Finney, M., Kalabokidis, K., \& Moore, P. (2017). Wildland fires. In N. R. Dalezios (Ed.), Environmental hazards methodologies for risk assessment and management (Ch. 9). London: International Water Association.

Ager, A. A., Kline, J., \& Fischer, A. P. (2015). Coupling the biophysical and social dimensions of wildfire risk to improve wildfire mitigation planning. Risk Analysis, 35(8), 13931406.

Alcasena, F. J., Salis, M., Ager, A. A., Castell, R., \& Vega-Garcia, C. (2017). Assessing wildland fire risk transmission to communities in northern Spain. Forests, 8(2), 27.

Arizona State Forestry. (2016). Arizona Wildfire Risk Assessment Portal 2016. Retrieved from https://www.arizona wildfirerisk.com/.

Balch, J. K., Bradley, B. A., Abatzoglou, J. T., Nagy, R. C., Fusco, E. J., \& Mahood, A. L. (2017). Human-started wildfires expand the fire niche across the United States. Proceedings of the $\mathrm{Na}$ tional Academy of Sciences, 114(11), 2946-2951.

Benayas, J. R., Martins, A., Nicolau, J. M., \& Schulz, J. J. (2007). Abandonment of agricultural land: An overview of drivers and consequences. CAB Reviews: Perspectives in Agriculture, Veterinary Science, Nutrition and Natural Resources, 2(57), 1-14.

Bodin, O., Crona, B., \& Ernstson, H. (2006). Social networks in natural resource management: What is there to learn from a structural perspective? Ecology and Society, 11(2), r2.

Borgatti, S. P., Everett, M. G., \& Johnson, J. C. (2013). Analyzing social networks. Thousand Oaks, CA: Sage Publications.

Calkin, D. E., Thompson, M. P., \& Finney, M. A. (2015). Negative consequences of positive feedbacks in US wildfire management. Forest Ecosystems, 2(1), 1-10.
Calkin, D. E., Thompson, M. P., Finney, M. A., \& Hyde, K. D. (2011). A real-time risk assessment tool supporting wildland fire decisionmaking. Journal of Forestry, 109(5), 274-80.

Charnley, S., Poe, M. R., Ager, A. A., Spies, T. A., Platt, E. K., \& Olsen, K. A. (2015). A burning problem: Social dynamics of disaster risk reduction through wildfire management. Human Organization, 74(4), 329-40.

Collins, B. M., Stephens, S. L., Moghaddas, J. J., \& Battles, J. (2010). Challenges and approaches in planning fuel treatments across fire-excluded forested landscapes. Journal of Forestry, $108,24-31$.

Csardi, G., \& Nepusz, T. (2006). The igraph software package for complex network research. InterJournal Complex Systems, $1695,1-9$.

Cumming, G. S., Cumming, D. H. M., \& Redman, C. L. (2006). Scale mismatches in social-ecological systems: Causes, consequences, and solutions. Ecology and Society, 11(1), 14.

CWPP Task Force. (2014). Community guide to preparing and implementing a Community Wildfire Protection Plan 2008. Retrieved from https://www.forestsandrangelands. gov/communities/documents/CWPP_Report_Aug2008.pdf.

Dether, D. M. (2005). Prescribed fire lessons learned: Escape prescribed fire reviews and near miss incidents. Boise, ID: Boise National Forest.

Dillon, G. K., Menakis, J., Fay, F. (2015). Wildland fire potential: A tool for assessing wildfire risk and fuel management needs. In R. E. Keane, M. Jolly, \& R. Parsons (Eds.). Proceedings of the large wildland fire conference. Proc. RMRS-P-73 (pp. 60-76). May 19-23, 2014. Missoula, MT: USDA Forest Service, Rocky Mountain Research Station.

Ellison, A., Knapp, M., Abrams, J., Nielsen-Pincus, M., Paveglio, T., \& Moseley, C. (2015). Community experiences with wildfire: Actions, effectiveness, impacts, and trends: Results from two surveys in counties and communities affected by wildfire. Eugene, OR: University of Oregon.

Fernandes, P. M., Botelho, H. S., \& Loureiro, C. (2002). Models for the sustained ignition and behaviour of low-to-moderately intense fires in maritime pine stands. In D. X. Viegas (Ed.), Forest fire research and wildland fire safety. Rotherdam: Millpress.

Finney, M. (2002). Fire spread probability (FSPro). Missoula, MT: USDA Forest Service, Rocky Mountain Research Station, Fire Sciences Laboratory.

Finney, M. A. (2001). Design of regular landscape fuel treatment patterns for modifying fire growth and behavior. Forest Science, 47, 219-28.

Finney, M. A. (2005). The challenge of quantitative risk analysis for wildland fire. Forest Ecology and Management, 211(1-2), 97-108.

Finney, M. A. (2006). An overview of FlamMap fire modeling capabilities. In P. L. Andrews \& B. W. Butler (Eds.), Fuels management-How to measure success. Proceedings RMRS-P41, 28-30 March (pp. 213-20). Fort Collins, CO: USDA Forest Service, Rocky Mountain Research Station.

Finney, M. A. (2007). A computational method for optimizing fuel treatment location. International Journal of Wildland Fire, 16, 702-711.

Finney, M. A., Grenfell, I. C., McHugh, C. W., Seli, R. C., Trethewey, D., Stratton, R. D., \& Brittain, S. (2011). A method for ensemble wildland fire simulation. Environmental Modeling and Assessment, 16, 153-167.

Finney, M. A., McHugh, C. W., Grenfell, I. C., Riley, K. L., \& Short, K. C. (2011). A simulation of probabilistic wildfire risk components for the continental United States. Stochastic Environmental Research and Risk Assessment, 25, 973-1000.

Fischer, A. P., \& Charnley, S. (2012). Risk and cooperation: Managing hazardous fuel in mixed ownership landscapes. Environmental Management, 49(6), 1192-1207. 
Fischer, A. P., Kline, J. D., Ager, A. A., Charnley, S., \& Olsen, K. A. (2014). Objective and perceived wildfire risk and its influence on private forest landowners' fuel reduction activities in Oregon's (USA) ponderosa pine ecoregion. International Journal of Wildland Fire, 23, 143-153.

Fischer, A. P., Spies, T. A., Steelman, T. A., Moseley, C., Johnson, B. R., Bailey, J. D., ... Bowman, D. M. J.S. (2016). Wildfire risk as a socioecological pathology. Frontiers in Ecology and the Environment, 14(5), 276-284.

Fischer, A. P., Vance-Borland, K., Jasny, L., Grimm, K. E., \& Charnley, S. (2016). A network approach to assessing social capacity for landscape planning: The case of fire-prone forests in Oregon, USA. Landscape and Urban Planning, 147, 18-27.

Gaines, L., Hemstrom, M., Kagan, J., \& Salwasser, J. (2013). Integrated landscape assessment project final report. Corvallis, OR: Institute for Natural Resources, Oregon State University.

Gardoni, P., \& Murphy, C. (2014). A scale of risk. Risk Analysis, 34(7), 1208-1227.

Guerrero, A. M., McAllister, R. R. J., Corcoran, J., \& Wilson, K. A. (2013). Scale mismatches, conservation planning, and the value of social-network analyses. Conservation Biology, 27(1), 34-44.

Haas, J. R., Calkin, D. E., \& Thompson, M. P. (2015). Wildfire risk transmission in the Colorado Front Range, USA. Risk Analysis, 35(2), 226-240.

Headwaters Economics. (2016). A comparison of two wildfire risk modeling approaches in Missoula County, Montana.

Jakes, P. J., Nelson, K. C., Enzler, S. A., Burns, S., Cheng, A. S., Sturtevant, V., ... Staychock, E. (2011). Community wildfire protection plannning: Is the Healthy Forests Restoration Act's vagueness genius? International Journal of Wildland Fire, 20, $350-363$.

Jolly, M., Cochrane, M. D., Freeborn, P. H., Holden, Z. A., Brown, T. J., Williamson, G. J., \& Bowman, D. M. J.S. (2015). Climate-induced variations in global fire danger from 1979 to 2013. Nature Communications, 6, 7537. https://doi.org/10.1038/ncomms8537.

Kalies, E. L., \& Yocom Kent, L. L. (2016). Tamm review: Are fuel treatments effective at achieving ecological and social objectives? A systematic review. Forest Ecology and Management, 375, 84-95.

Krasnow, K., Schoennagel, T., \& Veblen, T. T. (2009). Forest fuel mapping and evaluation of LANDFIRE fuel maps in Boulder County, Colorado, USA. Forest Ecology and Management, 257, 1603-12.

LANDFIRE. (2013). Homepage of the LANDFIRE Project. Retrieved from https://www.landfire.gov/index.php.

Lidskog, R., Soneryd, L., \& Uggla, Y. (2010). Transboundary risk governance. London: Earthscan.

Lidskog, R., Uggla, Y., \& Soneryd, L. (2011). Making transboundary risks governable: Reducing complexity, constructing spatial identity, and ascribing capabilities. Ambio, 40(2), 111-120.

Linnerooth-Bayer J., Löfstedt R. E., \& Sjöstedt G. (Eds.). (2001). Transboundary risk management. London/Sterling, VA: Earthscan.

MacDonald, D., Crabtree, J. R., Wiesinger, G., Dax, T., Stamou, N., Fleury, P., ... Gibon, A. (2000). Agricultural abandonment in mountain areas of Europe: Environmental consequences and policy response. Journal of Environmental Management, 59(1), $47-69$.

Miller, C., \& Ager, A. A. (2013). A review of recent advances in risk analysis for wildfire management. International Journal of Wildland Fire, 22(1), 1-14.

Moritz, M. A., Batllori, E., Bradstock, R. A., Gill, A. M., Handmer, J., Hessburg, P. F., ... Syphard, A. D. (2014). Learning to coexist with wildfire. Nature, 515(7525), 58-66.

MTBS Data Access. Fire level geospatial data. (2017, July - last revised). Retrieved from https://mtbs.gov/direct-download.
NFPA. (2015). Firewise communities in USA. Retrieved from https://nfpa.maps.arcgis.com/apps/Viewer/index.html?appid= c4a788340df748f18d98d8363145bb67.

North, M., Collins, B. M., \& Stephens, S. (2012). Using fire to increase the scale, benefits, and future maintenance of fuels treatments. Journal of Forestry, 110(7), 392-401.

North, M. P., Stephens, S. L., Collins, B., Agee, J., Aplet, G., Franklin, J., \& Fule, P. (2015). Reform forest fire management. Science, 349(6254), 1280-1.

OIG. (2016). Forest service wildland fire activities—Hazardous fuels reduction. Washington, DC: USDA Office of Inspector General, July Report No.: 08601-0004-41.

Omernik, J. M., \& Griffith, G. E. (2014). Ecoregions of the conterminous United States: Evolution of a hierarchical spatial framework. Environmental Management, 54(6), 1249-1266.

Parisien, M-A., Miller, C., Parks, S. A., DeLancey, E. R., Robinne, F-N., \& Flannigan, M. D. (2016). The spatially varying influence of humans on fire probability in North America. Environmental Research Letters, 11(7), 075005. https://doi.org/10.1088/17489326/11/7/075005.

Prichard, S. J., Stevens-Rumann, C. S., \& Hessburg, P. F. (2017). Tamm review: Shifting global fire regimes: Lessons from reburns and research needs. Forest Ecology and Management, 396, 217-233.

R Core Team. (2014). R: A language and environment for statistical computing. Vienna, Austria: R Foundation for Statistical Computing.

Radeloff, V. C., Hammer, R. B., Stewart, S. I., Fried, J. S., Holcomb, S. S., \& McKeefry, J. F. (2005). The wildland-urban interface in the United States. Ecological Applications, 15, 799805.

Renn, O., Klinke, A., \& van Asselt, M. (2011). Coping with complexity, uncertainty and ambiguity in risk governance: A synthesis. Ambio, 40(2), 231-246.

Richards, G. D. (1990). An elliptical growth model of forest fire fronts and its numerical solution. International Journal for $\mathrm{Nu}$ merical Methods in Engineering, 30, 1163-1179.

Rollins, M. G. (2009). LANDFIRE: A nationally consistent vegetation, wildland fire, and fuel assessment. International Journal of Wildland Fire, 18, 235-249.

Ryan, K. C., \& Opperman, T. S. (2013). LANDFIRE-A national vegetation/fuels data base for use in fuels treatment, restoration, and suppression planning. Forest Ecology and Management, 294, 208-216.

Sarkar, S., Pressey, R. L., Faith, D. P., Margules, C. R., Fuller, T., Stoms, D. M., ... Andelman, S. (2006). Biodiversity conservation planning tools: Present status and challenges for the future. Annual Review of Environment and Resources, 31, 123159.

Schalau, J., \& Twaronite, G. (2010). Wildfire risk reduction in Arizona's interior chaparral. Tucson, AZ: University of Arizona, Collge of Agricultural and Life Sciences Report No.: AZ1516.

Scott, J. H., \& Burgan, R. E. (2005). Standard fire behavior fuel models: A comprehensive set for use with Rothermel's surface fire spread model. Fort Collins, CO: USDA Forest Service. Rocky Mountain Research Station Report No.: RMRS-GTR153.

Scott, J. H., Thompson, M. P., \& Calkin, D. E. (2013). A wildfire risk assessment framework for land and resource management. USDA Forest Service, Rocky Mountain Research Station Report No.: RMRS-GTR-315.

Scott, J. H., Thompson, M. P., \& Gilbertson-Day, J. W. (2015). Exploring how alternative mapping approaches influence fireshed assessment and human community exposure to wildfire. GeoJournal, 82(1), 201-15. https://doi.org/10.1007/s10708-0159679-6. 
Short, K. C. (2014). A spatial database of wildfire in the United States, 1992-2011. Earth System Science Data, 6, 1-27.

Short, K. C. (2016). Spatial wildfire occurrence data for the United States, 1992-2013 [FPA_FOD_20150323]. (3rd ed.). Retrieved from: https://doi.org/10.2737/RDS-2013-0009.3.

Short, K. C., Finney, M. A., Scott, J. H., Gilbertson-Day, J. W., \& Grenfell, I. C. (2016). Spatial dataset of probabilistic wildfire risk components for the conterminous United States 2016. Retrieved from https://doi.org/10.2737/RDS-2016-0034.

SRA. (2013). Society for risk analysis. 2006. Retrieved from https://www.sra.org.

Steelman, T. (2016). U.S. wildfire governance as a social-ecological problem. Ecology and Society, 21(4), 3. https://doi.org/10.5751/ ES-08681-210403.

Stewart, S. I., Radeloff, V. C., Hammer, R. B., \& Hawbaker, T. J. (2007). Defining the wildland-urban interface. Journal of Forestry, 105(4), 201-207.

Trigo, R. M., Pereira, J. M. C., Pereira, M. G., Mota, B., Calado, M. T., DaCamara, C. C., \& Santo, F. E. (2006). Atmospheric conditions associated with the exceptional fire season of summer 2003 in Portugal. International Journal of Climatology, 26, 1741-1757.

UNECE/FAO. (2013). UNECE/FAO Regional forum on crossboundary fire management. United Nations.

U.S. Census Bureau. (2016). USA Census populated places areas 2016. Retrieved from https://www.arcgis.com/home/item. html?id=4e75a4f7daaa4dfa8b9399ea74641895.

USDA Forest Service. (2014). The National Strategy: The final phase in the development of the National Cohesive Wildland Fire Management Strategy.

USDA-USDI. (2001). National fire plan. A collaborative approach for reducing wildland fire risks to communities and the environment. Washington, DC: United States Department of Agriculture-United States Department of Interior.

USDA-USDI. (2013). A National Cohesive Wildland Fire Management Strategy: Challenges, opportunities, and national priorities. United States Department of Agriculture-United States Department of Interior.
USGS. (2016). Protected Areas Database of the United States (PAD-US). [Vector digital data.] 2016. Retrieved from https://gapanalysis.usgs.gov/padus/data/metadata.

Vaillant, N. M., \& Reinhardt, E. D. (2017). An evaluation of the Forest Service Hazardous Fuels Treatment Program-Are we treating enough to promote resiliency or reduce hazard? Journal of Forestry, 115, https://doi.org/10.1007/s00267-016-0791-2.

van Asselt, M. B. A., \& Renn, O. (2011). Risk governance. Journal of Risk Research, 14(4), 431-449.

Van Eerd M. C., Wiering, M. A., \& Dieperink, C. (2015). Solidarity in transboundary flood risk management: A view from the Dutch North Rhine-Westphalian catchment area. Climate Policy, 17(3), 1-19.

van Zwanenberg, P., \& Millstone, E. (2005). BSE: Risk, science and governance. Oxford, UK: Oxford University Press.

Williams, J. (2013). Exploring the onset of high-impact mega-fires through a forest land management prism. Forest Ecology and Management, 294, 4-10.

Wolf, J., \& Buckley, D. (2010). West Wide Wildfire Risk Assessment-State Forest Resource Assessment Data Survey Summary Draft Report.

WWWRA. (2013a).West Wide Wildfire Risk AssessmentDetailed Project Process Description. Oregon Department of Forestry, Council of Western State Foresters and the Western Forestry Leadership Coalition, March 31, 2013. Report No.: Detailed Project Process Description.

WWWRA. (2013b). West Wide Wildfire Risk Assessment-Final Report. Oregon Department of Forestry, Council of Western State Foresters and the Western Forestry Leadership Coalition, March 31, 2013. Report No.: Final Report.

Zachariassen, J., Zeller, K. F., Nikolov, N., \& McClelland, T. (2003). A review of the Forest Service remote automated weather station (RAWS) network. Fort Collins, CO: USDA Forest Service. Rocky Mountain Research Station Report No.: RMRSGTR-119.

Zaimes, G., Tufekcioglu, M., Tufekcioglu, A., Zibtsev, S., Corobov, R., Emmanouloudis, D., ... Trombitsky, I. (2016). Transboundary collaborations to enhance wildfire suppression in protected areas of the Black Sea region. Journal of Engineering Science and Technology Review, 9(1), 108-114. 